\title{
SINGING AND CODESWITCHING IN SEQUENCE CLOSINGS
}

\author{
Maria Frick
}

\begin{abstract}
Turns in interaction that initiate closure of expanded sequences are often summaries, accounts and assessments of the preceding talk. Sometimes these turns are produced by means that can be described as heteroglossic. This paper investigates singing and codeswitching in sequence closures, as well as other accompanying contextualisation cues such as prosodic changes and gestures. The heteroglossic character of these contextualised turns is a means for the speakers to distance themselves from the actions of their turns, and from the ongoing sequential activities. For the recipients this gives a possibility to make interpretations of non-seriousness. The sequences can then be closed with joint affiliative action such as laughter. In cases where the sequences have been expanded because of problems in interaction, singing and codeswitching relieve the tension between participants. On occasion, they also give rise to new topics. This paper is written in a conversation analytic framework, on data collected from everyday faceto-face interaction among Finns living in Estonia.
\end{abstract}

Keywords: Conversation analysis; Contextualisation cues; Code-switching; Singing in interaction; Teasing; Topic-shift; Conflict in interaction; Finnish; Estonian.

\section{Introduction}

A growing number of conversation studies in the past decades have found interest in the "extralinguistic" side of human interaction. While it is debatable whether a line can be drawn between what is "linguistic" and "extralinguistic", there is no doubt that phenomena such as prosody or gestures and facial expressions form an inseparable part of face-to-face-conversation. The research into how things are said include studies of figurative expressions (Drew \& Holt 1998) and codeswitching, that is: Switching between different languages (e.g. Auer (ed.) 1998). The study at hand contributes to the research on codeswitching in interaction. It also opens discussion on the topic of singing as a conversational activity. The main issue here is the investigation of how singing and codeswitching are used as contextualisation cues (Gumperz 1982) in conjunction with other such cues.

The data is drawn from videotaped everyday face-to-face interaction among Finnish families and friends living in Estonia. In the approximately 30 hours of conversation, there are approximately 20 instances of singing and two hundred code switches. This paper focuses on instances of conversational singing and codeswitching that occur in the closings of expanded sequences (cf. Schegloff 2007). The point of interest here is how these sequences come to an end, and what the role of singing and codeswitching in their closings is. Earlier research has found idiomatic and aphoristic 
formulations, jokes and the like to be common in sequence closures (ibid.: 186; Drew \& Holt 1998). These phenomena, like singing and codeswitching, represent heteroglossic language usage, which may be the reason why participants can use them to easily detach themselves from the preceding conversational activities. While this paper draws light on how this happens, it is not in its scope to wholly explain sequence closures, singing or codeswitching - let alone heteroglossia. This is no more than an account of some occurrences of these phenomena, one that aims at enhancing our understanding of the possibilities of everyday interaction.

Section 2 of the article presents an analysis of "dedicated sequence closing sequences", as named by Schegloff (2007), moving from ones where singing occurs, in 2.1, to ones with codeswitching, in 2.2 and then, in 2.3, to instances where attempts to initiate closure with singing or codeswitching fail at first. Section 3 draws conclusions regarding the role of contextualisation and heteroglossia in sequence closures, while section 4 focuses on how interactional discord and conflicts can get solved when sequence closure involves singing or codeswitching.

\section{Dedicated sequence closing sequences}

A sequence in interaction consists of a base, that is, an adjacency pair that forms the main action pair of the sequence, and possible expansions before, in between or after the base (Schegloff 2007). Sequences tend to be ended by the participants performing closing actions that are recognisable as such (Schegloff \& Sacks 1973). Sometimes a whole other sequence is dedicated to closing a sequence. Schegloff (2007: 186-187) describes what he calls dedicated sequence closing sequences as "little sequences used to close long sequences or topics". According to him (ibid.) they take various forms, but in their basic form they consist of three turns:

1. Initial turn, which proposes possible closing. Some of its forms are: Assessments, idiomatic or aphoristic formulations of the upshot or outcome of the sequence (see Drew and Holt 1998) and jokes which trade on, or are symbiotic with the sequence or topic. Many of these represent a stance taken toward that which may be ending.

2. The recipient may collaborate in closing down the sequence/topic, or withhold or even resist compliance.

3. A non-collaborative response can abort the sequence closing sequence. However, if the recipient has aligned with the initiating speaker, he or she may produce a final closing token and start a new sequence or topic.

Sequence closing sequences typically occur after longer sequences, such as ones that have been expanded (ibid.). Let's say a participant performs a request, but the other participant doesn't grant it and continues by explaining why he or she did not grant the request (or a third person takes a turn explaining it on behalf of the second participant). This is the kind of expansion that happens in Extracts (1) and (2) in sections 2.1 and 2.2. Another possible expansion type is a pre-expansion preceding a request such as the one in (3) in 2.3. In (4), the sequence is expanded first by assessment activity and then by a repair sequence. In all of these relatively long sequences one or more dedicated sequence closing sequences are used, containing either singing or codeswitching. In the 
transcripts, sequence closing sequences are marked with boxes and the turns that initiate them with boldface.

\subsection{Closure initiated by singing}

In (1) a line from a popular Christmas song is sung by one of the participants. This singing constitutes a turn in the ongoing conversation. It takes place after an episode of storytelling $^{1}$ that ends in mutual teasing by the storyteller and a recipient, followed by a request for affiliation from the storyteller to another recipient. When the requestee doesn't give the requested affiliation, another participant accounts for it: 'One can't defend someone/something like that'. The account (cf. Scott \& Lyman 1968; Antaki 1994) is followed by singing of the children's song: 'We are all mother's little piglets'. This results in affiliative action from all the participants, and the sequence is brought to an end with topic change.

The excerpt comes from a conversation among four friends in their late twenties /early thirties who are sitting in the living room of one of the participants, Liisa (Figure 1). The video recording has been going on for a little more than an hour. Mikko is sitting on the floor in front of the couch where Maija sits rubbing his shoulders. Two other friends, Liisa and Sari (who is not visible to the camera), are sitting nearby. The conversation is in Finnish, but takes place in Estonia, where the participants are studying $^{2}$.

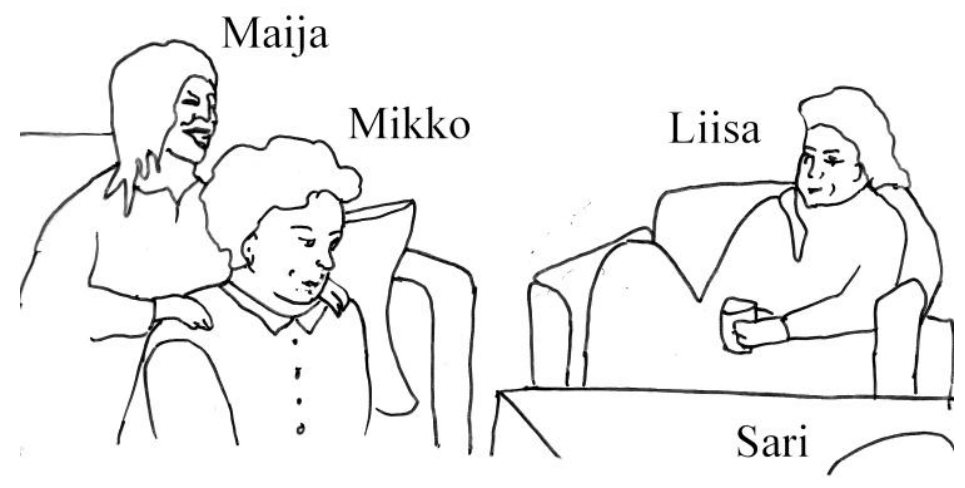

Figure 1

Extract (1) is from a complaint story told by Mikko, with contributions from Maija, about how they had had to cook in Liisa's apartment while Liisa was in the bedroom talking to her boyfriend Seppo on the phone. Mikko suggests that Liisa had been having phone sex when he and Maija were in the kitchen. The story is first presented as news,

\footnotetext{
${ }^{1}$ I use the term "storytelling", as suggested by Jefferson (1978), to denote a fragment of conversation that includes the "entry" into the story, the story itself and the "exit" from it.

${ }^{2}$ To be exact: The participants have lived in Estonia for the past six to seven years, but have preserved close contacts with Finland, for example by working there. Maija has just moved back to Finland a few months earlier, and is now visiting her old friends in Estonia. Liisa has also lived in Estonia earlier, as a child, then moved to Finland and back to Estonia as an adult.
} 
which makes Sari the main recipient of it - she is the only one who hadn't been present in the event. Sari is silent during the whole storytelling. Liisa on the other hand takes occasional turns challenging what Mikko and Maija are claiming. The storytellers complain about Liisa's actions, but they do so in a non-serious mood. The story contains laughter and exaggerations - elements that have been found in earlier studies of teasing (e.g. Drew 1987; Keltner et al. 2001; Haakana 1995; Tainio 2001; Lehtimaja 2006) ${ }^{3}$. Liisa's responses are typical of a person being teased: She laughs and shows she has understood the joke, but defends herself against the charges (Drew, ibid.). The beginning of the story, 67 lines, is not shown here.

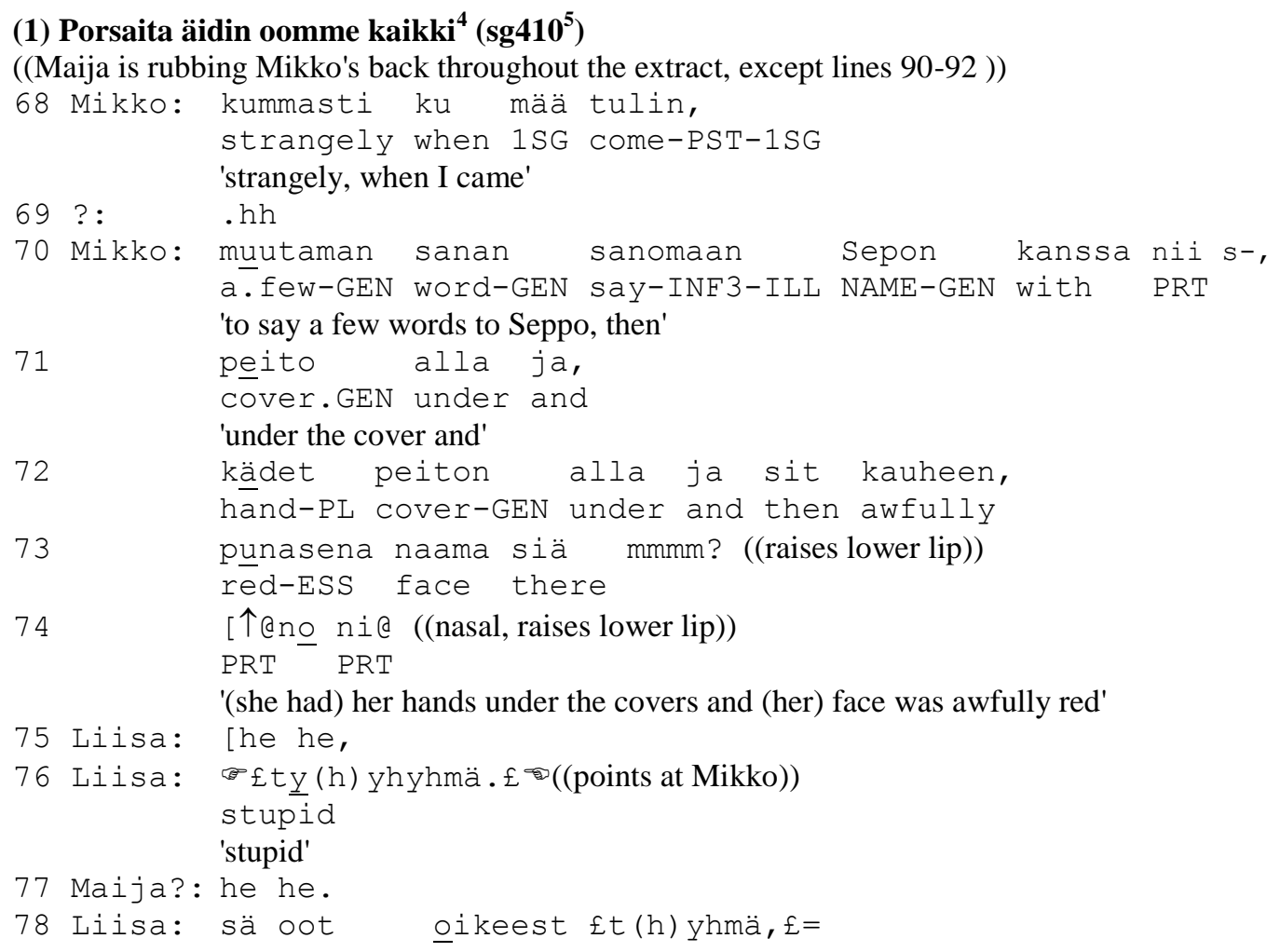

\footnotetext{
${ }^{3}$ Edwards (2005: 13) associates the occurrence of laughter in complaints with indirect ( $3^{\text {rd }}$ person) complaints, but laughter is also very common in the direct (co-present) complaints of the conversation at hand. One way to define (at least one type of) a tease, could be to say that is a co-present complaint marked with laughter.

${ }^{4}$ In the transcription each intonation unit is shown on a separate line. Some new symbols are introduced here: $\$$ (note) for 'singing'; (finger pointing right) for 'finger waving'; $\$$ (fingers pointing right and left) for 'finger waving or pointing throughout'; and b (black fist) for fist shaking. Under each transcript line there is a morpheme-by-morpheme gloss line, and idiomatic translations are given on a third line. Gaze, facial expressions and body movements are indicated selectively in double brackets. Note that prosody and laughter are marked only on the first transcription line, and that the idiomatic translations can only give a rough approximation of the meanings. The participants have given written consent for the transcripts to be used in research related publications. Their names have been changed.

5 The data are stored in the conversation archive of the University of Helsinki, Department of Finnish, Finno-Ugrian and Scandinavian Studies, under signum numbers indicated after the title of each extract.
} 
2SG be-2SG really stupid

$=£(\mathrm{~s} \ddot{\mathrm{a}}$ oot) nii likane (mies/mielik(h)u[vitus). $£$ 2SG be-2SG so dirty man/imagination

80 ?: 'you're really stupid, you are/have such a dirty (man /imagination)

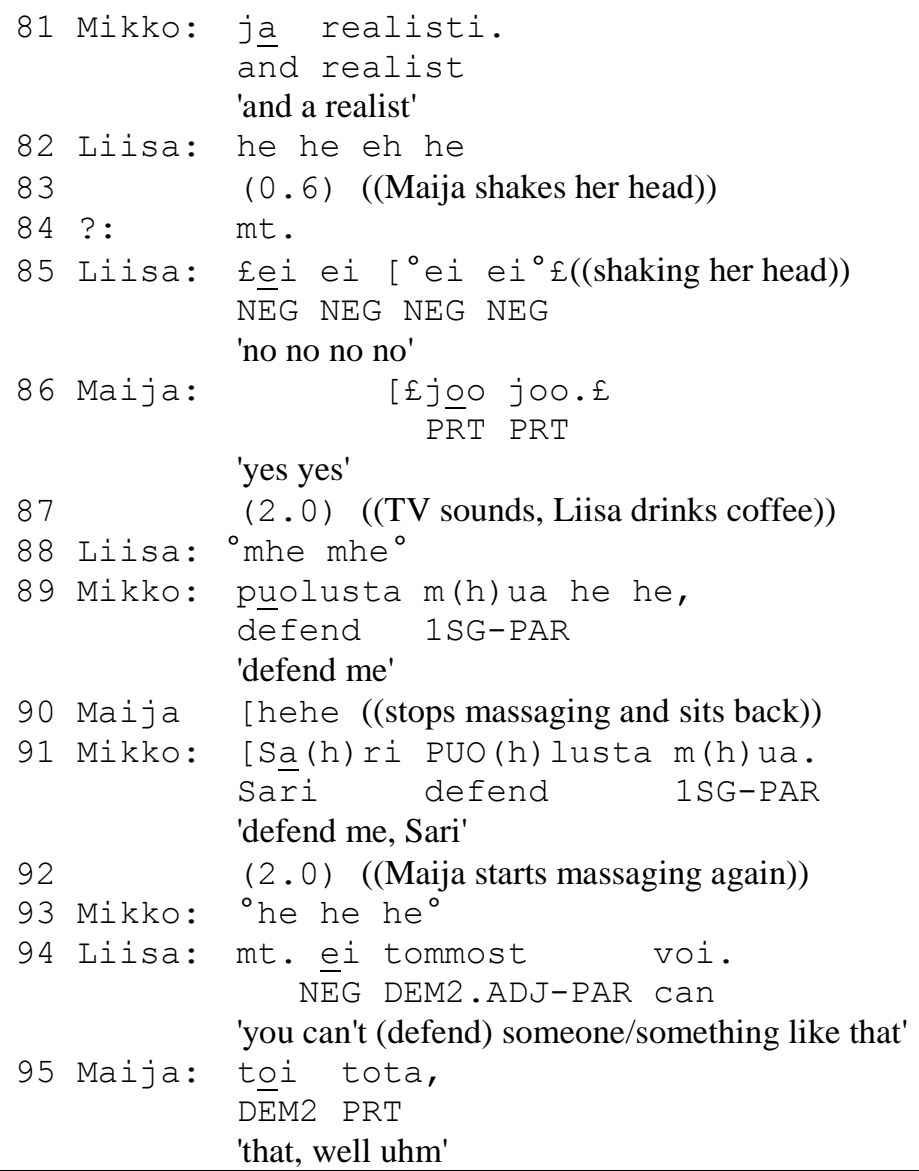




$$
\begin{array}{ll}
108 & (.) \\
109 & £ \text { karaokee. } £ \\
& \text { karaoke-PAR } \\
& \text { 'let's go sing karaoke' }
\end{array}
$$

Mutual teasing between Mikko, Liisa and Maija has been going on in the course of the storytelling, and also earlier in the conversation. This teasing doesn't only have to do with conversational transgressions like teases in Drew's (1987) data, but also with transgressions in earlier or ongoing conduct. For example, the speakers have told exaggerated stories of inappropriate things the others have done in the past. They have made joking remarks about what the others are doing and negative assessments of each other. Nevertheless, as Drew points out: "In the tease, abnormal or somehow deviant category or activity is attributed to the recipient". Here, the speakers engage in such teasing activity, where one tease follows another for long stretches of talk. In lines 6874 Mikko adds to the story a vividly animated description of how Liisa had looked when he had entered her bedroom. Liisa receives Mikko's narrative with laughter and then points at Mikko, assessing him in turn: 'Stupid, you are/have such a dirty (man/imagination)'. Mikko gives a second assessment 'and a realist', implying his enactment of the phone call event was truthful.

The sequence then shows signs of closure: Quiet laughter, particles ${ }^{6}$ and headshakes, and a pause. Sari, who hasn't said a word during the whole storytelling ${ }^{7}$, still remains silent. Her silence contrasts with the affective, animated mode of the others' interaction (on cues for affectivity in conversational storytelling, see Selting 2010). Not responding to a story directed to one can be regarded as a non-affiliative, dispreferred action (Jefferson 1978: 229). Since teasing is related to the closeness of the participants (Drew 1987), Sari's refraining from it can have to do with the fact that she is not an equally close friend with the others. In other words, she lacks the experience the others have, and cannot feel as strongly about Mikko's or Liisa's character. This kind of "feeling differential" can result in a story recipient avoiding explicit responses (Couper-Kuhlen, personal communication). Sari is also the person recording the conversation, which might affect the participation framework. While the others have teamed up (cf. Kangasharju 1998 and 2002; Heinemann 2009) in the mutual teasing (Mikko and Maija against Liisa in this particular stretch of conversation), Sari's silence is a way to avoid picking sides.

Sari is being made accountable for her silence by Mikko, who requests her to

\footnotetext{
${ }^{6}$ The Finnish negation particle $e i$ (ISK $\left.\$ 1625\right)$ is repeated four times here: ei ei ei ei. I am not aware of any studies of this kind of usage of the word, but in my experience it would be used, often as just a double $e i e i$, in the closing of storytelling, by the recipient, meaning something like 'that is so unbelievably funny $\sim$ terrible', 'that is so not true' or 'this is not happening'. It marks a transition from joking to a serious mode (Schegloff 2001). A turn initial ei can also be found on other kinds of interactional boundaries when moving from one activity to another: ei mut hei nyt lähetään 'PRT PRT PRT let's get going now' (Laury \& Etelämäki p.c.). The affective valence of the turn on line 85 has to be interpreted from prosodic cues and facial expression. Here Liisa is smiling, indicating a positive affect. If Liisa would be negating Mikko's previous turn '(I am) a realist', she would probably use a finite form of $e i$, for example et oo 'no you're not'. Maija replies with joo joo 'yes yes' as if repairing or opposing Liisa's negative assessment.

${ }^{7}$ Sari's face and body are hidden from the camera, so it is impossible to describe the non-verbal feedback she gives during the conversation.
} 
"defend" him (lines 89 and 91). According to Curl and Drew (2008), when making requests for action, people orient towards their entitlement to make the request on one hand, and towards contingencies associated with the requestee's ability to grant the requested action on the other. A request in the imperative mood, such as Mikko's request here, does not implicate contingencies or "effort" from the requestee (ISK §1661; Curl and Drew ibid.). Furthermore, there are no signs implicating lack of entitlement in Mikko's request. It is not accompanied by an account, and apart from the laughter, there is no such mitigation as, according to Schegloff (2007: 83), is "regularly found" in requests. In the context of Sari's dispreferred silence, Mikko shows full entitlement to ask for her contribution. Sari does not respond, that is, she doesn't grant Mikko's request. By doing so, she is again performing a dispreferred action (Schegloff 2007: 59; ISK §1216). It is Liisa, who then gives an account for why Sari had not granted the request (line 94).

In (1) we see the end of a long storytelling sequence, a request sequence and closings for both of these. This sequence in lines 96-105 closes all activity related to the request and storytelling that precede it. The situation is more complicated than the basic format described by Schegloff. There are four participants in the conversation, who all have to agree on closings. Liisa initiates the first sequence closure with an assessment in lines 78-79, Mikko produces a second assessment in line 81, the sequence closes after some minimal exchange and a pause, but Mikko initiates an expansion with a request. Another sequence closing sequence is then initiated by Liisa in line 96 with the singing of Porsaita äidin oomme kaikki 'We are all mother's little piglets'. ${ }^{8}$

Just before Liisa's singing, Maija has started a turn (line 95), one that seems like an initiation of a new topic with a demonstrative pronoun (cf. Laury 1997: 146; Etelämäki \& Jaakola 2009). She does not finish her turn, but gives room for Liisa's singing. Liisa, being the previous speaker (before Maija), continues with a second turn, the singing, which thus blocks a possible topic change. That is, Liisa treats the ongoing topic as unfinished and continues it. But how are "mother's piglets" a continuation of the previous talk? To understand this, we need some contextual information. First, calling people pigs is a common insult in Finnish. Second, there is a semantic connection of pigs to the word 'dirty' in Liisa's earlier assessment of Mikko: 'You have such a dirty imagination'. And, third, 45 minutes earlier, Mikko has identified himself as a pig by producing grunt-like snorts and a piggy-nose gesture ${ }^{9}$ identical to the one he is about to produce now (in lines 98, 103 and 105, figure 2).

\footnotetext{
${ }^{8}$ Liisa sings with a quiet voice, except for the first syllable, which is louder. The reactions from Maija and Mikko are much louder in volume. This is not quite consistent with the regular usage of sequence closing sequences, where the successive turns tend to be produced with declining volume and pitch (Schegloff 2007: 187; Couper-Kuhlen 2004, cf. also lines 78-86 in (1)).

${ }^{9}$ The gesture is inspired by an Estonian TV-show, Vremja, that the participants imitate earlier in the conversation. The characters in the show have the tips of their noses pinned up, like in Mikko's gesture. The show does not however make reference to pigs - this is probably Mikko's own association.
} 


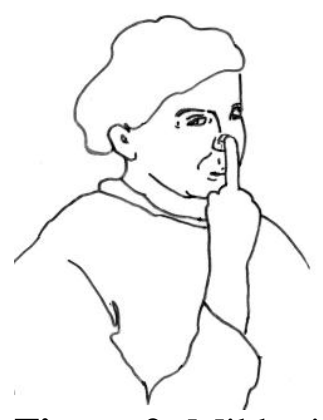

Figure 2: Mikko in line 103

Actionwise, Liisa's singing turn is an elaboration of her earlier 'one cannot (defend) something/someone like that'. It explains what she has meant by tommosta: Something or someone piglike. The turn is an assessment. But Liisa is no longer assessing only Mikko - she doesn't change the wording of the song. Perhaps it is the $1^{\text {st }}$ person plural in the song, that "we" are "all" piglets, that invites the other participants to join in a common oinking (lines 97/98-105). Mikko produces grunting snorts, while Maija reacts twice with a rhythmical röh röh 'oink oink'. Mikko then pulls the tip of his nose up (Figure 2), Liisa laughs and Mikko oinks again ${ }^{10}$. This affiliative joint activity is minimal in the sense that it does not call for continuation. In this aspect, it is similar to laughing together (cf. Jefferson et al 1987: 169-170; Haakana 1999: 109-132) - an activity which shows "rapport and consensus" (Adelswärd 1989). With this joint enactment of pigs, the participants distance themselves from the serious context of dispreferred actions.

The singing gives rise to a new topic, when Maija suggests going to sing karaoke. Jefferson (1984) notes that after complaint sequences, participants tend to choose topics that are not related to the complainable matter. This is true here too. While karaoke as a topic is related to singing, it has nothing to do with the two problems in the preceding talk: Liisa's telephone call and Sari's not participating in the conversation. In fact, the latter problem gets solved as Sari engages in the talk about karaoke.

\subsection{Closure initiated by codeswitching}

Blom and Gumperz (1972) were probably the first to study codeswitching in recorded conversational data and report its usage in topic shifts ${ }^{11}$. Codeswitching in topic shifts is most often reported to happen so that a new topic is started in a new language. A relatively recent account is provided by Lappalainen (2004: 296-303), whose data show Finnish speakers shifting from a colloquial to a standard variety when making topic

\footnotetext{
${ }^{10}$ It is unclear from the tape, whether Liisa and Sari participate in the reactions following the singing. There is audible sound on lines 97 and 102. Sari's face is not shown, but Liisa is smiling and moving her lips slightly.

11 See also McClure 1977: 24; Gal 1979: 117; Gumperz 1982; Auer 1995; Goyvaerts \& Zembele 1992: 76; Zentella 1997: 93-94; Kovács 2001: 121-122; Li Wei 2002: 167-169; Zabrodskaja 2005: 84-86; Saari 2009: 221-222 etc.
} 
summaries and other closing initiations.

The participants in (1) are Finns living in Estonia, and the main language of the conversation is Finnish. The next example (2) shows how these same speakers use codeswitching to Estonian. The turn that initiates sequence closure is Mikko's aga abikaasa töö on ju olla abiline 'but a wife's job is to be a helper' in lines $21-22^{12}$. The stretch of conversation in (2) is similar to (1) in that it too goes from teasing to a request that is rejected, and then to a justification of the rejection. Maija and Sari have left the room and gone to the adjoining kitchen. Just preceding (2), the four friends have joked around the idea that Mikko and Maija could get married. This has been done in a loud voice from one room to another - Liisa and Mikko are now alone in the room with the camera.

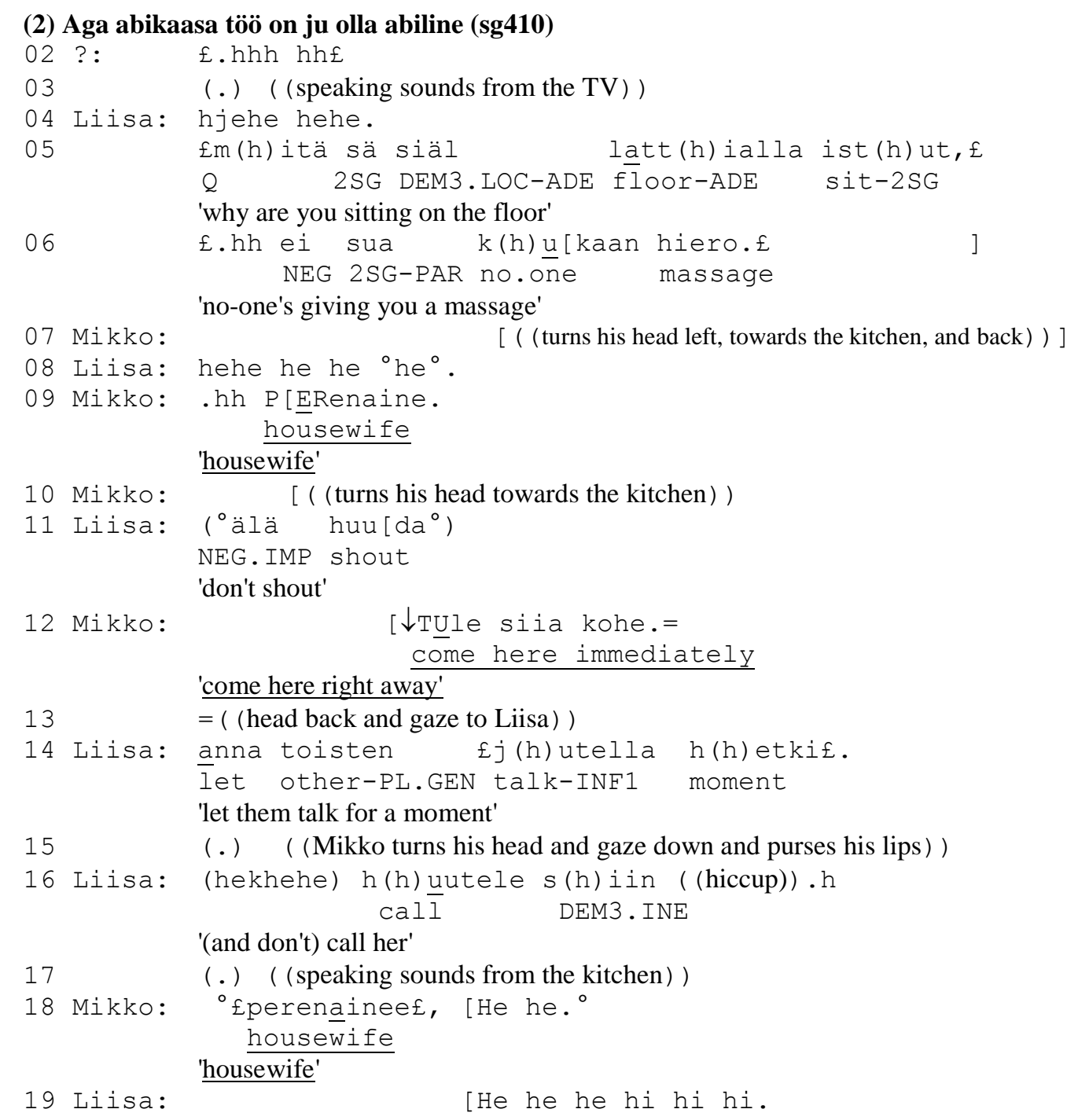

\footnotetext{
${ }^{12}$ The morphemes uttered in Estonian are underlined on the gloss and translation lines. In turns that contain codeswitching, words that can be either Finnish or Estonian are underlined with a broken line. Where there is metalinguistic talk (about the meanings of words), these words are given in the original language also on the translation line.
} 


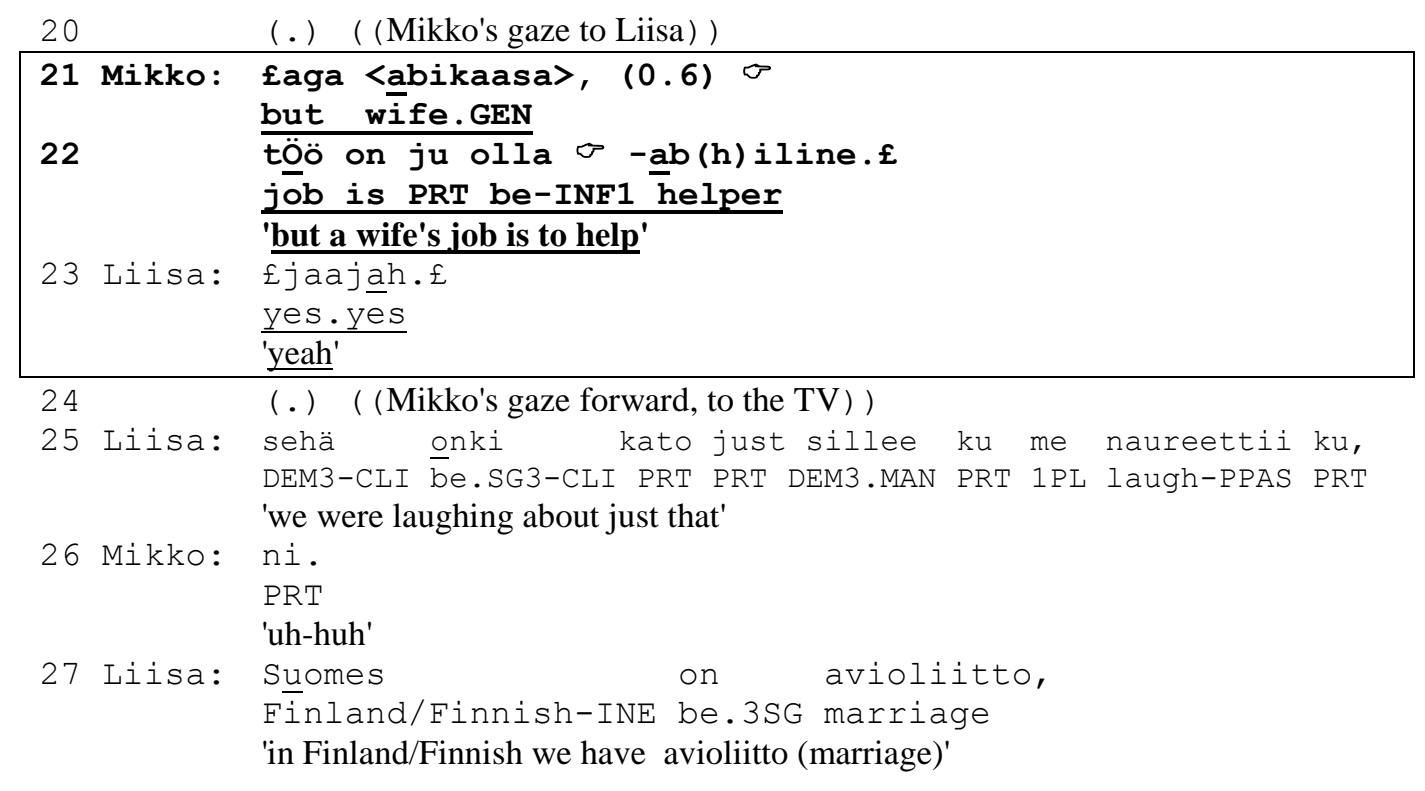

Liisa starts a new sequence (lines 5-6), laughing about Mikko sitting on the floor. The first part of Liisa's turn (line 5) doesn't start with the question word miksi 'why', but with mitä 'what' (as in the English 'what are you doing sitting on the floor for'). This type of a question is often seen as reproachful or deprecating, it implicates a negative assertion 'you shouldn't be doing that' (ISK §1706, 1688), and according to ISK (§1706) they can, but need not be answered. It is true that Liisa's turn does not necessarily call for a literal answer of the kind that requests for information do. It does, however, call for a certain kind of recipient action. Liisa's turn is an action that Sacks (1995, II: 115119) has named a challenge, that is, 'a request for an explanation or justification' (see also Koshik 2003; Keevallik 2011). Challenges can also be seen as a type of co-present complaint, because the challenger reproaches the recipient for his actions. Liisa's turn implicates that Mikko has no reason to sit on the floor, now that Maija has left the room and is not rubbing his shoulders anymore, and calls for an explanation or justification of that. Mikko's response is to start calling Maija. Getting his masseuse back would justify his sitting on the floor, which would nullify the grounds for Liisa's challenge/complaint.

Throughout the conversation Mikko has called Maija perenaine, an Estonian word that can be translated 'hostess', 'housewife' or 'landlady' ${ }^{13}$. This is the word he uses now. Mikko's summons for Maija is done in Estonian, with a falling pitch in line 9 and a low voice in line 12 and in an imperative mood that is reinforced with a temporal qualifier: Perenaine, tule siia kohe! 'Housewife, come here right away!'. In contrast to his previous turns, these ones are not marked with laughter. This stopping of laughter, prosodic changes, lexical and grammatical choices and codeswitching indicate a change in the speaker's footing, i.e. they act as contextualisation cues. These are indications that Mikko is not speaking in his own previous voice, but has assumed a role (cf. Goffman

\footnotetext{
${ }^{13}$ The data doesn't reveal the origin of this nickname. Maija is not the hostess of the evening; the gathering takes place at Liisa's home. Neither is she a landlady or a housewife in real life.
} 
1981: 144; Gumperz 1982: 34; Lappalainen 2004: 303-306). He is now speaking with the voice of someone who gives serious, low-pitch orders to Maija. One of the local interpretations of Mikko's turn, indicated by Liisa's reaction by laughter that appears in the end of her next turn, is that he is in fact not being serious in his seriousness. Another interpretation can be made on the grounds of the speaker's language choice (Estonian) possibly having some meaning potential for the interactants.

Liisa then makes a three-part request for Mikko to stop calling (lines 11, 14 and 16). The Finnish word toinen 'other', when used in complaints, can signal the speaker's identifying with the "other" (ISK §767) or, in this case, defending the "other", choosing their side. Liisa's turns in lines 5 and 16 contain a modifier 'there': Siellä, siinä that can be used in reproaches (cf. ISK §1706). Liisa's turn in line 16 starts as a serious one, but is filled with so much laughter towards the end that one cannot make out her first word. The laughter reopens the joking mood; Liisa, while scolding Mikko, indicates with laughter that she has understood that Mikko is joking. Mikko reacts with a fake(?) indicator of being hurt: He lowers his head and shoulders, looks down and makes a "sad face" (Grant 1969: 528) by turning down the corners of his mouth. Mikko does this simultaneously with the third part of Liisa's turn (line 16), just after signs of laughter start showing in Liisa's speech. While Mikko shows being hurt by the serious first part of Liisa's request, Liisa modifies her turn further by filling it with laughter. Liisa's laughter is thus not only a reaction to Mikko's earlier turn, but also to his body posture and facial expression. Liisa does not seem to regard Mikko as being seriously hurt laughter would not be a preferred reaction to that - but has interpreted Mikko's action as a joke. Mikko repeats his summons perenaine (line 18), but now with a soft, whispery voice, smiling and ending his turn in laughter. The change in his tone is a concession to Liisa's request 'not to shout', but the turn defies the request 'not to call'. Liisa joins the laughter, and Mikko then proceeds to the closing of the sequence with aga abikaasa töö on olla abiline 'but a wife's job is to be a helper'.

Mikko's turn in lines 21-22 is in Estonian. It is an account, a justification for the speaker's earlier action that another participant had complained about - his summons for Maija, perenaine. Mikko makes a generalised claim that a wife's job is to be a helper. Taken in the context of the preceding topic, a joke about Mikko and Maija getting married, the 'wife' in this turn would refer to Maija. The claim that a wife should help, is based on the word 'spouse', abikaasa, in Estonian containing the word 'help', abi. It is a pun: Both the word for 'spouse' abikaasa and 'helper' abiline, in Estonian, start with $a b i$ 'help' ${ }^{\prime 14}$. The turn is produced in an emphatic style (cf. Selting 1994) with a prominent stress on every content word. This makes the turn sound like Mikko is "stating his last word" on the matter. Mikko points his forefinger towards Liisa and waves his hand and whole body in the rhythm of his speech giving it a beat (McNeill 1992: 169) that emphasises the words abikaasa 'wife's' töö 'job' and abiline 'helper'. There is a pause between the two words of the subject NP that, besides emphasis, could also indicate processing; selecting wording for the turn (word-searches are found in

\footnotetext{
${ }^{14}$ Although folk ethymologies commonly associate the words abielu 'marriage' and abikaasa 'spouse' with the word $a b i$ 'help', it is probable that these words are etymologically of the same root as the Finnish avio 'marriage',the meaning of which is traced back to 'open' or 'public' (Mägiste 1949).
} 
some of Drew and Holt's (1998) examples of idiomatic expressions in the same sequential position).

Mikko's codeswitched pun 'a wife's job is to be a helper' fits Schegloff's description of the first pair part to a dedicated sequence closing sequence (2007: 186) as it sums up the preceding talk. Though the turn is created by Mikko here and now, it is formulated as if it were a saying - similar to those that can be found in sequence closings (Drew \& Holt 1998; Schegloff ibid.). This is done with the particle $j u$ that marks the turn as common information, something that 'everybody knows' (EKSS).

The second pair part is found in line 23, where Liisa shows agreement jaajah 'yes' ${ }^{\prime 15}$. As Drew and Holt (ibid.) point out, the recipients to such closing initiations tend to keep their agreement tokens minimal, thus orienting towards a closure by avoiding any further elaboration of the topic. Liisa's turn is in Estonian. Following the language choice of the previous turn is a further indicator of cohesion and agreement (as compared to codeswitching that would create a contrast). After jaajah Liisa moves to a new topic in Finnish: She starts comparing the Finnish and Estonian words for 'marriage'.

\subsection{When sequence closure fails}

Sometimes even sequence closing sequences get expanded. This happens, according to Schegloff (2007: 187), when the recipient continues to talk on the sequence/topic whose closure had otherwise been made relevant, or when a second pair part shows something other than "agreement/alignment" with the previous turn. The next three extracts exemplify this. In (3) the sequence is expanded by one of the recipients, who continues the assessment activity for several turns. The sequence closing sequence in (4), on the other hand, is expanded with a repair sequence, and the one in (5), when the recipient responds with silence.

In (3), an assessment with codeswitching (line 22) does not end the sequence, but one that is sung does (lines 28-29). The extract in (3) is recorded during a Finnish students' game and sauna evening in Estonia, where six people are sitting around the table, four of them (Teppo, Raili, Tuija and Sari) playing dice and the other two holding a parallel discussion. A non-participating person is standing nearby. When a new person (Jarkko) enters the room, Sari greets him and starts talking about the ongoing recording. She asks Jarkko a question that turns out to be a prerequest: Does it bother him that there is a recorder in the room. Jarkko replies that it doesn't bother him, but that he is not going to stay long. This part of the sequence is not shown in (3).

(3) Suuri ja mahtava Helsinki (sg424)

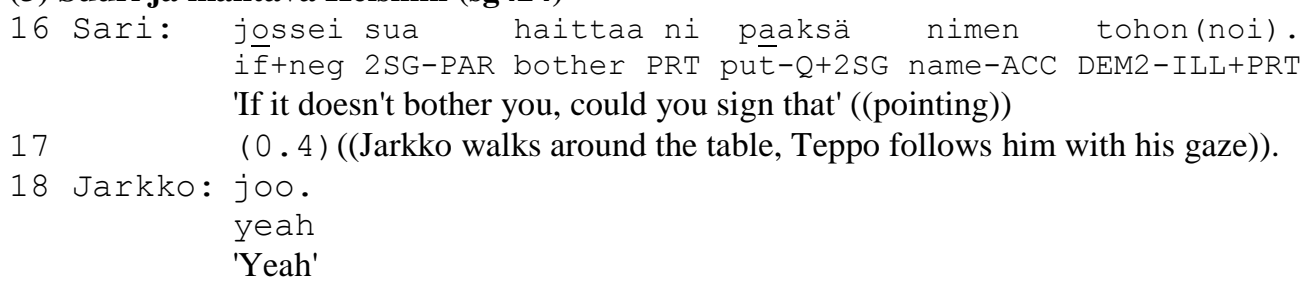

${ }^{15}$ See Kasterpalu 2005 on Estonian agreement tokens. 


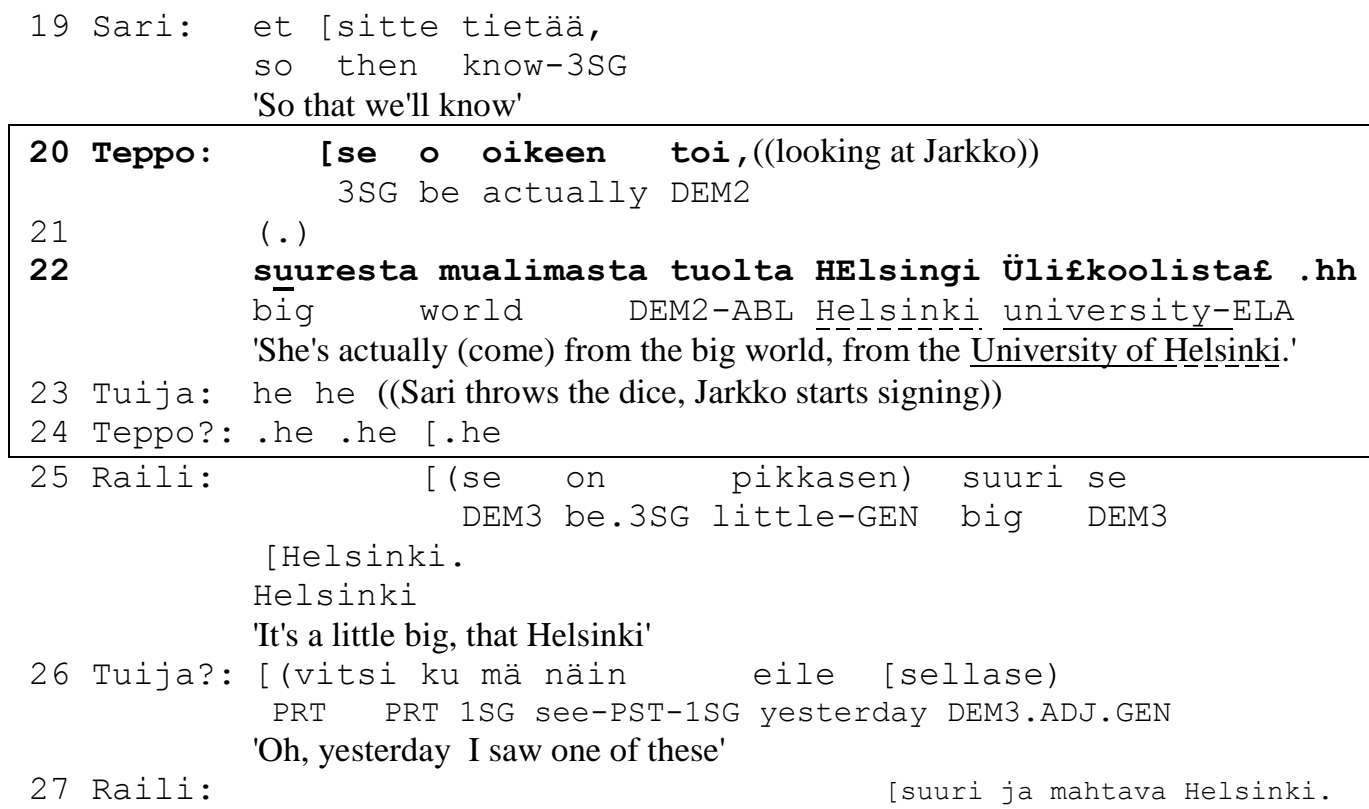

'Great and sublime Helsinki'

(. ) ((Risto and Sepi stop talking and turn to look at Raili and Teppo))

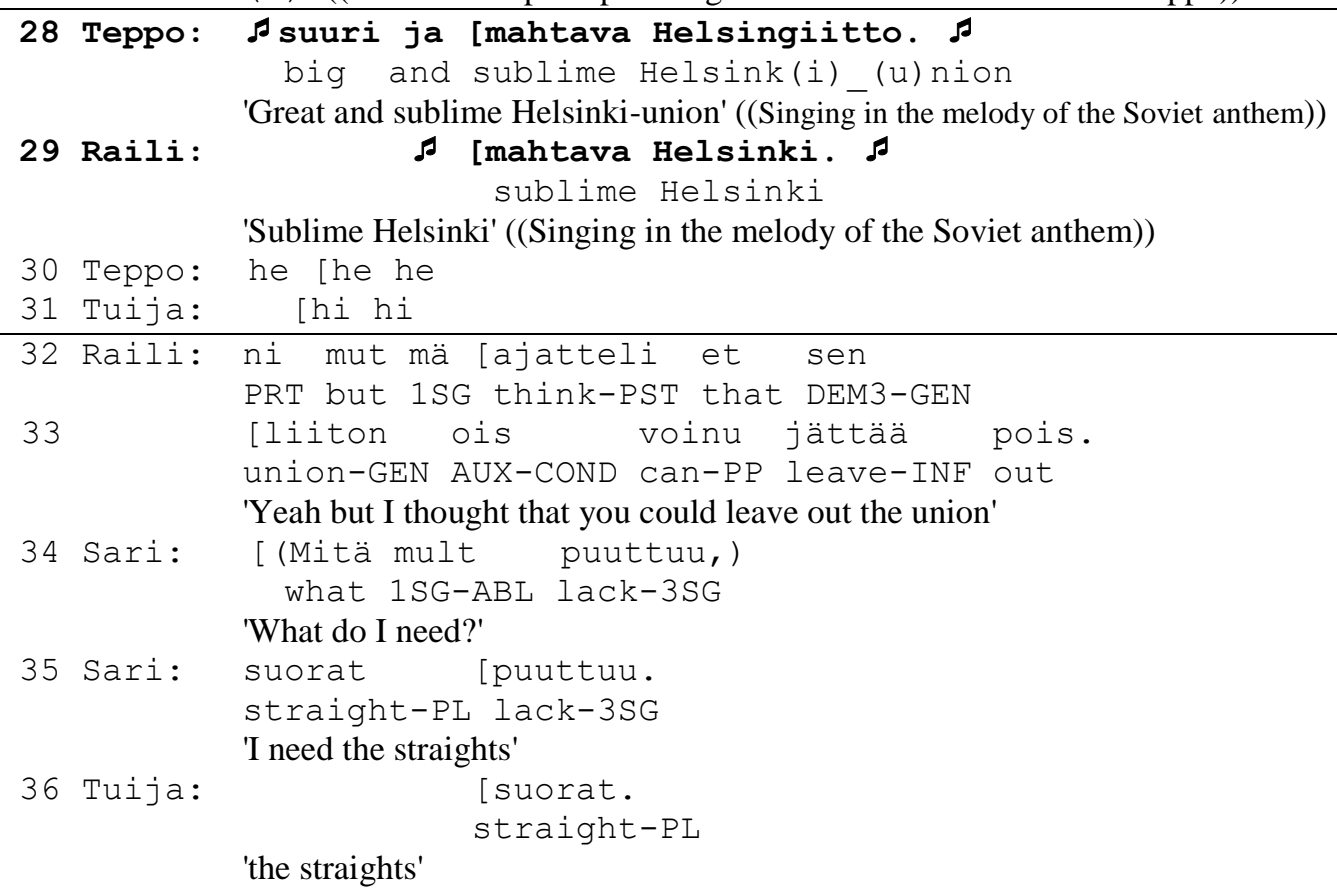

Sari makes a request for Jarkko to sign a consent form (line 16). She accounts for the request both before (line 16) and after (line 19) the request: 'If you don't mind' and 'so we know'. The latter utterance is left syntactically unfinished (lacking an object). Jarkko agrees to sign the form (lines 17-18) and does so (line 23ff). All in all, the request sequence is quite long and not unproblematic. There is a presequence and accounts by 
the requester, and a partial rejection by the requestee of the prerequest: 'I don't mind, but I won't be staying long'. Sari might also assume that Jarkko has seen a first request: A paper on the door asking all people present to sign a consent form, and she therefore orients towards a possible rejection from Jarkko. Jarkko, however, starts granting the request by walking around the table to where the consent form lies (Figure 3).

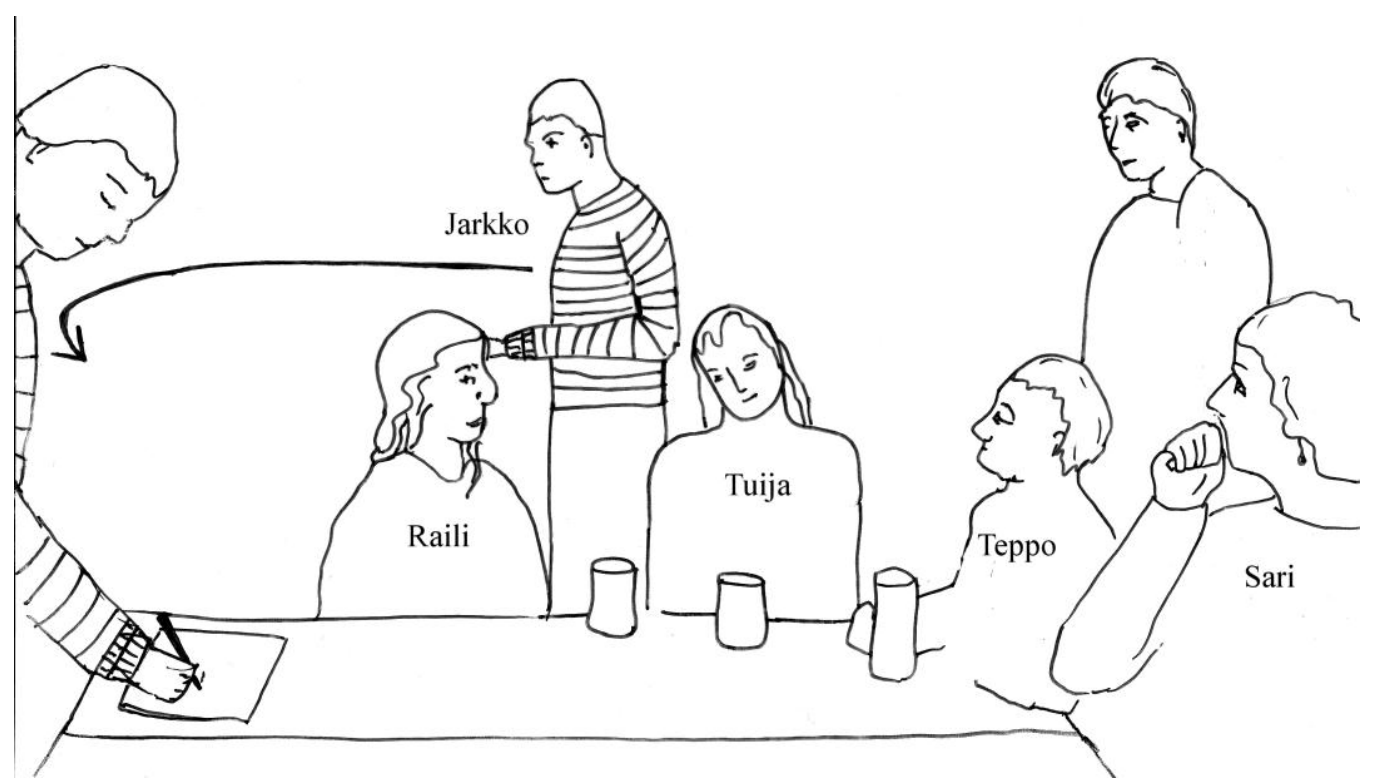

Figure 3: Lines 17-23 (Jarkko walking around the table)

It becomes evident that for Teppo and Raili, who have been silent onlookers to the request sequence, the topic needs further treatment and closure beyond mere granting of the request. This is done in a somewhat humorous mode, contrasting with the seriousness of the request sequence. While producing his turn in lines 20 and 22, Teppo follows Jarkko with his gaze. This turn is an informing of something Sari has left unsaid, and it thus contributes to the request sequence. It is also an assessment of Helsinki and the University of Helsinki. It goes back to where the request sequence had started, Sari telling about the recording. Returning to the start is something that initiating turns of sequence closing sequences sometimes do according to Schegloff (2007: 186). The turn contains an idiomatic expression 'from the wide world' using a dialectal form of the word mualima 'world', and an Estonian word ülikool 'university' ${ }^{16}$. The word Helsinki is pronounced with emphasis, and the turn ends in a smile and three laughter particles produced with inbreath (line 24).

Teppo's assertion is met with laughter from Tuija and Teppo (lines 23 and 24). This can indicate non-seriousness: Both participants treat Teppo's turn as ironical. Laughing together is connected to closing down longer topics (Haakana 1999: 118-123).

\footnotetext{
${ }^{16}$ A variety of terms could be used to describe different kinds of occurrences of two languages in one stretch of conversation. I use the term codeswitching as a cover term for both longer switches as in (2) and (4), and the one-word switch in (3). The Estonian word (Helsingi) ülikooli-sta in (3) is inflected with a Finnish suffix, and would be called a "(nonce) borrowing" by e.g. Poplack (2000 [1980]: 224-226) and Gumperz (1982: 66), "codeswitching" by Myers-Scotton (1992) and Halmari (1993), "insertion" by Muysken (2000), a "global lexical copy" by Johanson (1999) etc. The inflection of Finnish-Estonian switches is discussed in Frick 2008.
} 
Raili does not however treat the topic as closed, but instead, she makes a second assessment about Helsinki being big. This assessment can be analysed as a second turn to a sequence closing sequence. It being in agreement with the first one, the sequence should be ready to close (cf. Schegloff 2007:187). Tuija treats it so and overlaps with Raili's right dislocation, attempting to start a new topic by starting to tell about something she has seen (line $26^{17}$ ). But Raili overlaps with Tuija and rephrases her assessment using an expression suuri ja mahtava 'great and sublime', which is recognisable as part of the Finnish lyrics of the Soviet anthem. At this point, the floor is open for the duration of a micropause: Tuija does not pursue the topic she started; Risto and Sepi stop the parallel conversation they have been holding for a while and turn to look at Raili and Teppo. Teppo sings the first line of the Soviet anthem, replacing the word Soviet with Helsinki: 'Great and sublime Helsinki union'. Raili joins in the singing of: 'Sublime Helsinki'.

In (3) the sequence closing sequence is expanded by reiterations of the initial assessment, not only in a second assessment turn, but several. The last of these turns is done by singing. The participants in (3) are not aligning as to when exactly the sequence is supposed to end. Tuija attempts to start a new topic already in line 26, but the others agree to end the sequence only when joint laughter (lines 30-31) follows a singing together (lines 28-29). A similar pattern was shown in (1), where Maija attempted a new topic (line 95), but Liisa continued the ongoing assessment activity by singing, which resulted in topic change after some joint minimal affiliative action (laughing and pig-enaction). In (3) the topic changes when Raili comments on her singing (line 32), and again when Sari poses a question about the ongoing game.

Extract (3) showed how a dedicated sequence closing sequence that contained codeswitching was not enough to end an activity that had pulled the participants' attention away from the game they were playing, and how one containing singing was. The next extract, (4) on the other hand, shows how the participants make several closing attempts with codeswitching. Example (4) includes a series of assessments that are produced using a combination of verbal and nonverbal action, that is, speech, gestures and codeswitching from Finnish to both Estonian and English. The participants are affiliative, but not aligned as to the organisation of the sequence: They fight for the floor. The sequence also gets expanded by a repair initiated by a word search. Extract (4) is the continuation of (2).

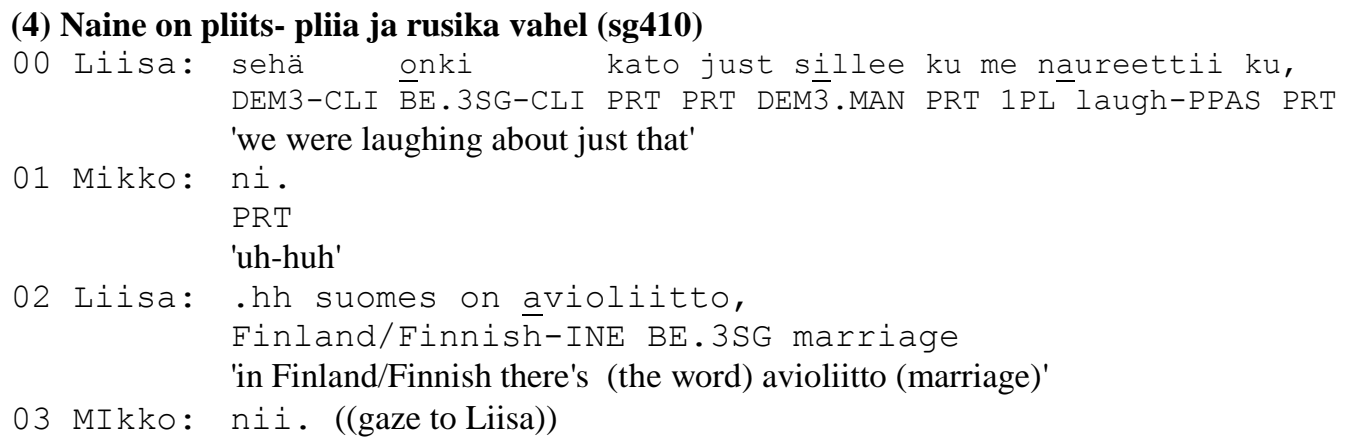

\footnotetext{
${ }^{17}$ The turn on line 26 is hard to hear from the tape, so it is possible that the speaker is not Tuija, and that these are not the exact words she uses.
} 


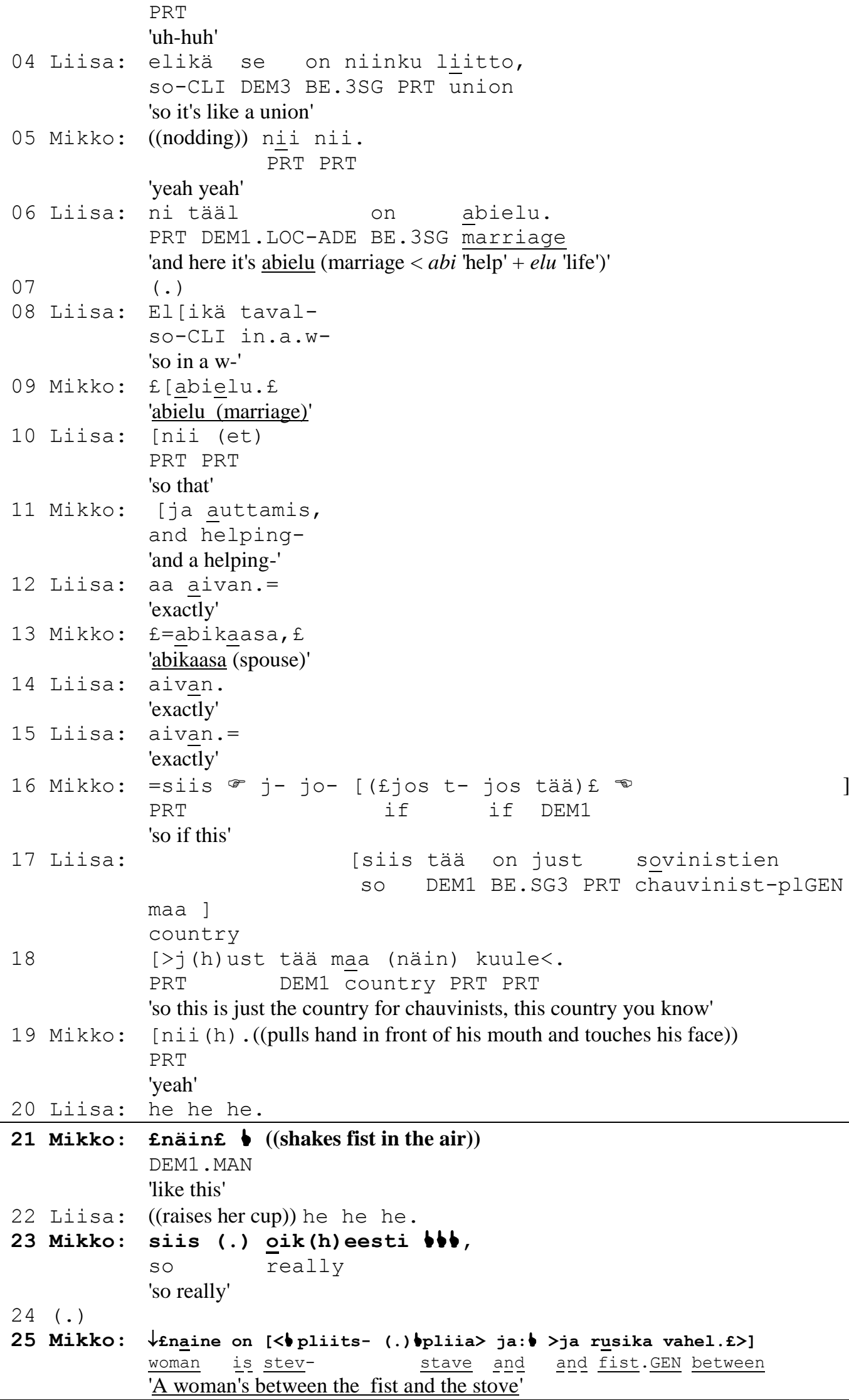




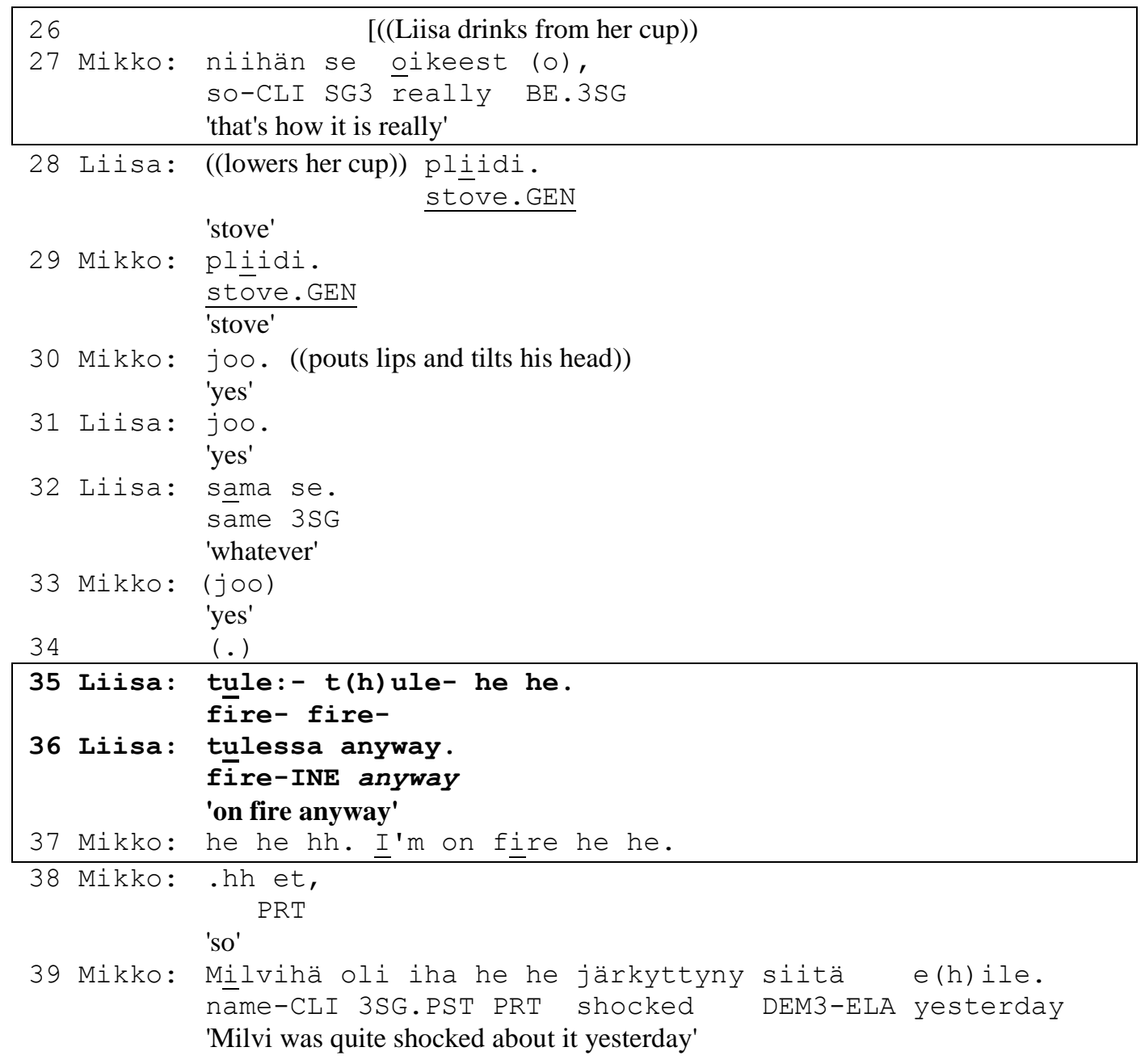

When Liisa brings up the different words for marriage, Mikko's responding with ni, nii, and nii nii shows affiliation and an orientation towards something that follows (cf. Sorjonen 2001: 131-166). What follows is that Mikko starts a turn 'so i- if this' waving his finger at Liisa (line 16), but Liisa overlaps with him, producing an assessment. Liisa's turn is a conclusion of what has been said earlier: The word for 'marriage' in Estonian reflects what she calls "chauvinism" in the country. Mikko agrees (line 19) in overlap with Liisa's increment. Lines 18-19 could well make up a dedicated sequence closing sequence, but Mikko expands on it by making a second assessment, which consists of three turns: 1) 'like this' and a gesture, shaking his fist (line 21); 2) siis oikeesti 'so really' and three fist shakes; and 3) a figure of speech in Estonian: 'A woman is between a stove and a fist' (line 25). These make up an assessment that is affiliating with what Liisa has just said (cf. Pomerantz 1984; Stivers 2008; Couper-Kuhlen 2012). Mikko's figure of speech does, however, not close the sequence. There is a word search in it, where Mikko looks for the word 'stove' in Estonian. This initiates a repair that expands the sequence (lines 29-36). Only after managing the repair is the sequence brought to an end, this time with a figure of speech in English (line 37). A new topic is 
introduced, one that does not seem to be related to any prior talk: Mikko and Liisa start talking about a friend they had met the day before.

Extract (4) is discussed further in the next section which focuses on the heteroglossic characteristic of singing and codeswitching that may have to do with why these phenomena occur in the closings of expanded sequences and what is achieved by them. The next section also touches the question of social indexing.

\section{On contextualisation, heteroglossia and social indexing}

Songs used in conversation are recontextualised texts (Englebretson 2010; cf. Schegloff 2005). As the above extracts show, lines from for example a Christmas song or an anthem can be used in everyday speech situations. The context of an everyday conversational activity is not where these songs are typically heard, and they are used in a relatively unexpected way to serve the interactional needs in a conversational setting. The songs can be sung in their original wording as in (1), or their words can be modified to better fit the current speech situation as in (3), where Helsingiitto 'Helsinki Union' is sung instead of Neuvostoliitto 'Soviet Union'.

The usage of songs in the conversations discussed above is somewhat different from the singing of pop-music by schoolchildren that Rampton (2006) has investigated. In his data, the children's choices of songs are indexical of their social roles and their taste in music. In the everyday conversations under investigation here, this is not very evident. The speakers in (1) do not position themselves as Christmas-loving people, nor are the speakers in (3) showing any specific relation to the Soviet Union. They do make use of text (a melody) that is not their own, but recognisable as something foreign to the speech situation. This is why these recontextualised songs can be compared to reported speech. The authorship of the songs is however not made relevant in the conversations: The participants have no way of recognising whose voice the speaker is using. These songs are common texts, available to use by the speakers and recognisable, but they are not authored by anyone in particular. In this sense they resemble sayings and other figurative expressions studied by Drew \& Holt (1998). Bakhtin's (1982) notion of heteroglossia is useful for describing what is done with figurative expressions or the songs in (1) and (3), as well as the codeswitching in (2) and (4).

The heteroglossia of the songs in (1) and (3) as well as figurative expressions is a little different from that indicated by codeswitching, because the latter does not use a prior text. There is however evidence in recorded data (not shown here) that people sometimes sing turns of conversation not by using known songs, but in words and melodies of their own, made up there and then. This kind of singing is close to such heteroglossic speech (that can be marked with codeswitching) where no known text is being recontextualised. Namely the kind where speakers signal a change in footing, that is: Their "alignment, set, stance, posture or projected self" (see Goffman 1981).

Changes in footing such as in reported speech can be marked with prosodic cues (e.g. Voloshinov 1973; Goffman ibid.; Gumperz 1982 and 1992; Couper-Kuhlen \& Klewitz 1999; Couper-Kuhlen 1999; Günthner 1999), embodiment (McNeill 1992: 169; Niemelä 2010) or codeswitching as in the data discussed here (cf. e.g. Goffman ibid.; Gumperz 1982; Auer 1995; Kalliokoski 1995; Leisiö 1998; Lo 1999; Lappalainen 
2004). These changes in the production mode function as contextualisation cues that, in Gumperz's (1992: 232) words "serve to highlight, foreground or make salient" parts of the text. Contextualisation cues are any verbal or nonverbal signs that help speakers hint at, or clarify, and listeners evoke the cultural background and social expectations necessary to interpret speech (Duranti \& Goodwin 1992: 229).

A turn in (2), Mikko's assertion Abikaasa töö on ju olla abiline 'A wife's job is to be a helper', makes up a pun in Estonian, one that could not be done in any other language. There are however other factors, in addition to "making it sound good", that probably contribute to Mikko's using Estonian in this turn. Throughout the day, Mikko has been calling Maija perenaine 'housewife'. Also his strict summons for her was in Estonian. Just seconds earlier the participants had joked that Mikko and Maija could get married. Mikko seems now to be playing the role of a demanding husband, and is using Estonian as a contextualisation cue. Is he perhaps playing the role of someone he sees as typically Estonian?

In her study of Hungarian-German bilinguals in Austria, Gal (1979) observed that codeswitching to German was used as a culmination of disagreement and angry arguments, as "a last word that was not outdone" (ibid 117). She concludes that for the speakers, German is a language of prestige, urban sophistication and authority. Many later researchers seem to agree that the meaning of codeswitching cannot be reduced to any inherent social meanings that the choice of language would index in any given interactional situation (e.g. Gumperz 1982: 66; Álvarez-Cáccamo 1990; Auer 1995, 1998: 2-3; Li 2002). This becomes clear also from the data at hand - switches to Estonian do not necessarily signal the speakers' attitudes or social connotations assigned to the languages. Still, a look into the conversation shown in extracts (2) and (4) reveals the participants' understanding of the connection between language and social roles. In (4), Liisa and Mikko compare the Estonian and Finnish words 'marriage': Abielu and avioliitto respectively. Liisa stresses the fact that the Finnish word has the word liitto 'union' in it, while the Estonian word has literally to do with 'helping'. Mikko and Liisa co-construct a list of words, and Liisa then concludes that 'this is a country for chauvinists'.

In (4), Mikko's assessment (lines 21-27) is made up of a heteroglossic multimodal construction and a codeswitched figure of speech. A fist shake is a somewhat conventionalised gesture with a recognisable meaning that has been lexicalised as heristää nyrkkiä 'shake one's fist (at someone)' in Finnish. Mikko frames it with a proadverbial näin 'like this ${ }^{18}$. When doing this, he is not shaking his fist at Liisa, but is telling her about fist shaking. Or rather, about someone shaking a fist. As the construction follows Mikko's nii 'yes', he seems to be elaborating on Liisa's assessment of Estonia being a chauvinistic country: 'Yes, like this +fist shake'. It is thus the Estonians, in Mikko's performance, doing the fist shaking. He is doing, in Clark and Gerrig's (1990) words "a demonstration" of someone else's fist shaking - or of someone's negative attitude that is symbolised by a fist shake. The fist is also indexical of the saying Mikko is about to produce: 'A woman is between the stove and the fist'.

The figure of speech in (4) is produced with a smile voice, a low onset and first slowing and then accelerating the tempo. It contains a word search and three rhythmical

\footnotetext{
18 See Jääskeläinen 24.5.2007 on constructions [näin + gesture].
} 
fist shakes. These fist shakes are beats, which according to $\mathrm{McNeill}$ highlight certain words in the speech, signalling "that the word they accompany is part of some other context than the one that it is immediately presented in" (1992: 169). The prosody and gesture are contextualisation cues that support the heteroglossia of the recontextualised text. Another cue is codeswitching. Mikko chooses to produce the saying in Estonian, despite the fact that it would probably be more easily available for him in Finnish. The saying is not known in Estonian (though quite widespread in Finnish). The turn also shows Mikko searching for the right word for 'stove' in Estonian and not finding it. This suggests that there is a socio-pragmatic reason for Mikko to go through the trouble of using Estonian in this turn: $\mathrm{He}$ is speaking with an Estonian voice. This usage of Estonian is at the same time evaluative of what Mikko perceives as typically Estonian. $\mathrm{He}$ is reporting thoughts and attitudes that he himself is critical of (cf. e.g. ÁlvarezCáccamo 1996; Leisiö 1998). ${ }^{19}$

Heteroglossia distances the speaker from what is being said (Bakhtin 1982; Gumperz 1982: 34; Besnier 1990: 426; Kalliokoski 1995; Günthner 1999). He is no longer the sole principal (Goffman 1981) of his words and can thus not be held completely responsible for what is being said. This disengagement of the speaker from the primary action of his turn (for example a justification) might play a role in why singing and codeswitching elicit affiliative responses even when there is interactional discord in the ongoing stretch of conversation. The next section focuses on the resolving of such dissonance.

\section{Resolving interactional discord}

The speakers in (1)-(4) are not totally aligned regarding the sequential activity, that is, when and how to close the sequence and topic. They show disagreement on the propositions made, but the disagreeing arguments are mitigated by signs of humour and irony. In the end, the speakers all seem to agree that Mikko has a dirty imagination (1), that there's no reason for him to sit on the floor if no one is rubbing his shoulders (2), that Helsinki and the university there are not really that big (3), and that Estonia is a chauvinistic country (4). After one or more post-expansions, the sequences come to an end. While in (3) the sequence fails to end with codeswitching (line 22), but ends with singing (lines 28-29), the one in (4) is brought to an end with several code switches to different languages.

When looking at the extracts presented in this paper, we can imagine a situation where there would have been a topic change earlier. Let's say that in (1) Maija's attempt to start a new topic would have succeeded and the sequence would have ended after $E i$ tommost voi 'One cannot (defend) someone/something like that' (line 94). Or that in (3) the speakers would have gone with Tuija's attempted topic shift, and the sequence would have ended after the ironical Se on pikkasen suuri se Helsinki 'It's a little big, that Helsinki'. Why didn't the other participants go along with a new topic - why did they, instead, decide to prolong the preceding topic with a sequence closing sequence?

\footnotetext{
${ }^{19}$ On reported speech and indirect evaluation see also Voloshinov 1973; Couper-Kuhlen \& Klewitz 1999; Couper-Kuhlen 1999; Günthner 1999.
} 
If the sequences had ended earlier, dissonance would have been left in the air in both (1) and (3) - about whether or not Mikko's actions were defensible, and about whether or not Helsinki was really considered big. But the sequences get expanded by other participants, who end up singing (or codeswitching) after which the sequences can end. After studying figurative expressions at sequence closure, Drew and Holt (1998: 521) suggest that "The matter of securing the other's agreement, affiliation, or sympathy may be of some interactional moment..." The idea that singing and codeswitching are used as a resource for resolving interactional conflict is supported by what we see following them, that is, the "supportive interchange" (Vuchinich 1990: 130; cf. Goffman 1971) in the form of repeated particles and laughter by the participants. By laughing together - or grunting, in (1) - the speakers show that they have achieved affiliation, a shared positive emotive stance.

The data given above have shown how singing and codeswitching are used in closing expanded sequences that include signs of dispreference. In extracts (1)-(2) requests are not granted, in (3) the requester marks the request as accountable, and (4) is expanded by a repair sequence. Regardless of these problematic actions, the overall spirit in these sequences is positive. This is achieved by the participants quickly attending to the dispreferred actions and guiding the interaction towards joint affiliative activities. Where there are co-present complaints, they are of the teasing kind: Ones treated with laughter. The dissonance created by the dispreferred actions in (1) - (4) never lasts for very long.

As an example of how a more lengthy conflict is managed by interactants, consider (5). The base of (5) is a request (line 41) that is not immediately granted. The extract is taken from a quarrel, where the participants make co-present complaints and respond to them with counter-complaints. The tone of the conversation is serious. The participants show heightened emotive involvement (Selting 1994) by raising their voice, using extreme and idiomatic formulations as well as third/zero person reference to the recipient and a voiced animation of the other participant in a 'whining' tone (cf. e.g. Ochs \& Schieffelin 1989; Couper-Kuhlen 1999; Goodwin \& Goodwin 2000; Hakulinen \& Laitinen 2008; Heinemann 2009; Selting 2010; Laitinen 1995; Yli-Vakkuri 1986: 110). The beginning of the quarrel is not shown here.

Extract (5) is from the $6^{\text {th }}$ hour of a 10-hour recording in a couple's home on a Saturday. Tapio is finishing up cooking and Timo talking about going to the store. Tapio complains about him leaving when it's dinnertime. The young men both complain about how the other "always" acts in such situations. After a lengthy pause, Tapio makes a request:

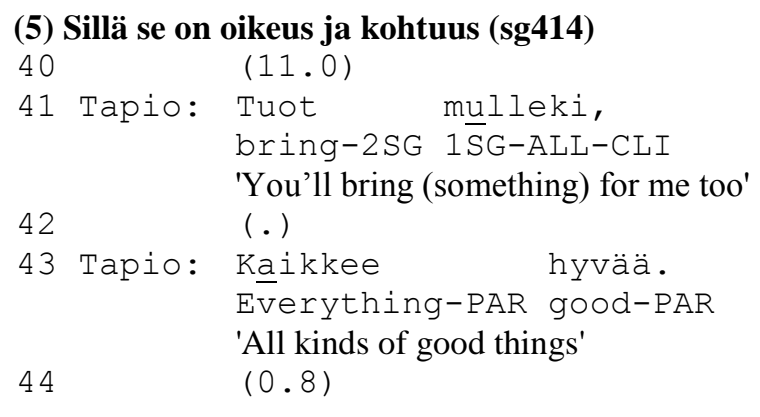




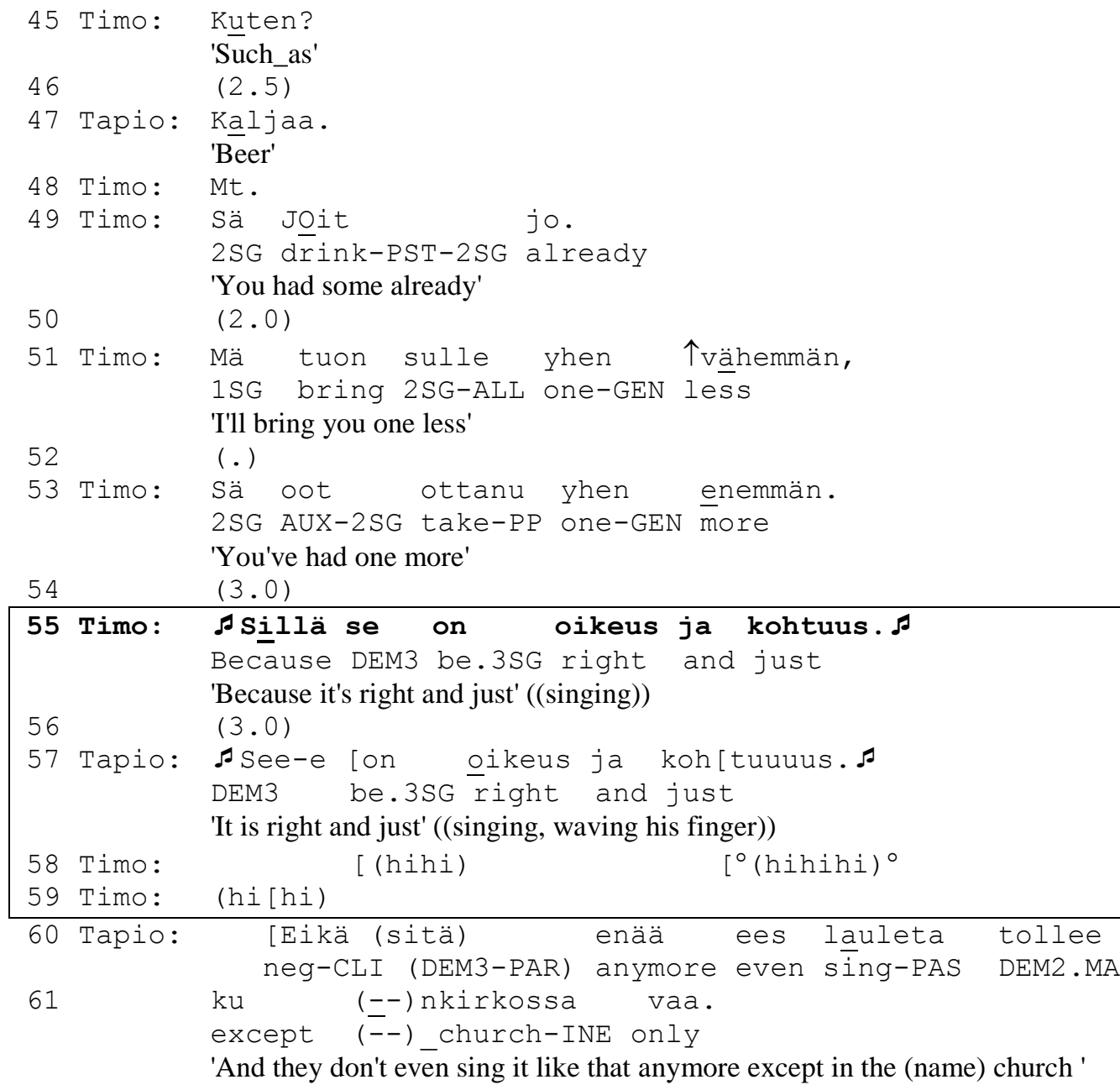

Tapio's request for Timo to bring him some "good stuff" from the store (lines 41-43) can be seen as his assent to Timo going to the store, a concession saying 'it's alright for you to go, if I too benefit from it'. Tapio's request is made in a blunt indicative mood, the English equivalent of which could be 'You'll bring...!' Instead of accepting the request, which would be considered a preferred response, Timo initiates a repair (line 45) asking what Tapio would like him to bring, and Tapio asks for beer. Timo still doesn't agree, but instead, starts arguing why he shouldn't do the requested action: Tapio had had some beer already (line 49). Tapio doesn't take a turn.

In his investigation of family conversations, Vuchinich (1990) finds that one of the ways by which people terminate disputes is compromise (concession). According to him, when speakers offer a concession ${ }^{20}$, they signal that they are ready to close the conflict, but not submit. He points out that conceding is face-threatening since it requires the speakers to alter positions they have previously taken, and to trust that it will not be used against them (ibid: 127-130). In (5) Timo makes a concessive offer: He will bring Tapio one beer less than himself (line 51). Timo's turn in line 51 is produced using an almost cheerful tone with a high rise on the last word. This contrasts clearly

\footnotetext{
${ }^{20}$ Here the term "concession" is used somewhat differently than in the studies of concessive patterns by Couper-Kuhlen and Thompson (2000), where request sequences are not under investigation.
} 
with his previous, angry turn (line 49). This concessive offer is followed by the speaker's account for it: A justification stating that Tapio has had one beer more than Timo. By justifying his action, the speaker shows that he has performed a dispreferred social action on one hand, and that he is not totally responsible for it on the other (Scott \& Lyman 1968). Tapio still doesn't take a turn. Timo does not treat Tapio's disengagement from the argument as an assent, but chooses to give further account for his concessing offer.

In Vuchinich's data (ibid.), an offer of concession is eventually followed by an assent that accepts the offer, though this might only happen after several conceding turns. In one of his examples a compromise closing is achieved when one of the participants makes an ironic joke ${ }^{21}$. Timo's turn (line 55) is produced by singing. Timo's singing in line 55 'For it is right and just' is a Finnish version of a Eucharistic prayer. It is identifiable as an account because of its initial word sillä 'because ${ }^{22}$. The recipient, Tapio, does not, however, respond to the accounting action of Timo's turn. After a pause, he finally takes a turn, singing a different melody of the same prayer (line 57). Tapio never assents to Timo's conceding offer to bring him one beer less. Instead, he chooses not to take a turn until after Timo's singing. Tapio's usage of the clitic $-k \ddot{a}$ 'and' and word ees 'even' in line 60 lead to the interpretation of Tapio's singing (line 57) as a repair of Timo's turn - it is possible that Tapio hasn't recognised the less known melody that Timo uses ${ }^{23}$. Repairing Timo's melody is a way for Tapio to maintain some opposition to Timo without verbally engaging in the dispute. Timo receives Tapio's singing with laughter, which is a "final closing token" (Schegloff 2007: 186). Jefferson (1984) has found that devices that lead out of troubles-telling are topically disjunctive: That is, whatever happens after troubles-telling "does not emerge from it, is not topically coherent with it, but constitutes a break from it". Tapio starts a new topic (line 61) discussing the singing of the Eucharistic prayer in church. The usage of the prayer song in church makes a good candidate for a new topic, because it is unrelated to the situation at hand, so the discussion is turned away from the dispute.

In Extract (5) Sillä se on oikeus ja kohtuus 'For it is right and just' is an account for the speaker's dispreferred proposal (to give his spouse one beer less from the shop). It is a singing that constitutes a turn and a social action in conversation. The same can be said of the singings and code switches in the previous extracts.

\section{Conclusions}

This article has shown that singing and codeswitching are contextualisation cues used in sequence closures. They appear in spots where interactional tension has been built up in post-expansions of troublesome sequences - ones where the speakers are not affiliating

\footnotetext{
${ }^{21}$ See also Norrick \& Spitz 2008 on humour as a resource for conflict mitigation.

${ }^{22}$ Sillä 'because' associates with a literary style and is not widely used in colloquial Finnish. It was not found among the 182 accounts investigated by Raevaara (2009), who lists account-initial particles to include $k u(n)$, koska, kato (kun), että and niin.

${ }^{23}$ Both Timo's and Tapio's melodies have been used in the Evangelic Lutheran Church of Finland, though Timo's version is less known. The words have recently been changed, which is what Tapio refers to on lines 60-61. I am indebted to Melisa Stevanovic for this information.
} 
with each other or are not aligned as to who can take a turn and when the sequence should end. More specifically, singing and codeswitching can be seen in the initiation of closings, in turns that sum up, assess or account for the preceding talk. Singing and codeswitching, as well as figurative expressions that can be found in the same sequential position, are heteroglossic - they are recontextualised texts spoken in a voice that is not entirely the speaker's own.

Singing and codeswitching often occur together with other contextualisation cues such as gestures and changes in prosody. Despite their formulation and fitting in the sequence as any regular turn-action, the heteroglossic nature of these contextualised utterances gives the recipients room for an alternate interpretation beyond the actions proposed by the wording of these turns. This gives the recipients a chance to react by laughing or joining in other kinds of minimal affiliative action. The participants thus achieve a shared positive emotive stance, after which they can move to other activities. On occasions, they draw from the intertextual material of songs and different languages and switch to a new topic concerning those.

While the interactional locus investigated here (sequence closing sequences) is by far not the only environment where singing and codeswitching occur, it is one where their pragmatic potential gets well utilised. For the members of the Estonian Finnish community studied here, these two heteroglossic cues are powerful devices for changing the course of interaction.

\section{Acknowledgements}

I would like to thank Elizabeth Couper-Kuhlen, Ritva Laury, Marja-Leena Sorjonen, Anna Verschik, Marja Etelämäki, Marjo Savijärvi, Aino Koivisto, Melisa Stevanovic and Anna Vatanen for their insightful comments on earlier drafts of this paper. Others, too numerous to name here, have shared their observations about the data, of which I am most grateful. I would also like to thank the anonymous reviewer(s) for their useful remarks. This research was funded by the FiDiPro project 'Grammar and interaction: The linking of actions in speech and writing', University of Helsinki.

\section{Abbreviations}

1SG, 1PL etc. 1st person singular, 1st person plural etc. (verbal and nominal suffixes, personal pronouns)

ABL ablative 


\begin{tabular}{|c|c|}
\hline $\mathrm{ACC}$ & accusative \\
\hline $\mathrm{ADE}$ & adessive \\
\hline ADJ & adjective \\
\hline ALL & allative \\
\hline AUX & auxiliary verb \\
\hline CLI & clitic \\
\hline $\mathrm{CON}$ & conditional \\
\hline DEM & demonstrative \\
\hline DEM1 & $1^{\text {st }}$ demonstrative (tä̈̈ etc) \\
\hline DEM2 & $2^{\text {nd }}$ demonstrative (toi etc) \\
\hline DEM3 & $3^{\text {rd }}$ demonstrative (se etc) \\
\hline ELA & elative \\
\hline ESS & essive \\
\hline GEN & genitive ( accusative $-n)$ \\
\hline ILL & illative \\
\hline IMP & imperative \\
\hline INE & inessive \\
\hline INF & infinitive \\
\hline INF1 & A- /DA-infinitive $\left(1^{\text {st }}\right.$ infinitive $)$ \\
\hline INF3 & MA-infinitive ( $3^{\text {rd }}$ infinitive) \\
\hline LOC & locative \\
\hline MAN & manner \\
\hline NEG & negative \\
\hline PAR & partitive \\
\hline PAS & passive \\
\hline PL & plural \\
\hline PP & past participle \\
\hline PPAS & past passive \\
\hline PRT & particle \\
\hline PST & past \\
\hline Q & question \\
\hline TRA & translative \\
\hline
\end{tabular}

\section{Transcription marks}

$\begin{array}{ll}\cdot & \text { falling pitch } \\ , & \text { level pitch } \\ ? & \text { rising pitch } \\ \uparrow & \text { shift to high pitch } \\ \text { heti } & \text { stress }\end{array}$




\begin{tabular}{|c|c|}
\hline[ & overlap (start) \\
\hline ] & overlap (end) \\
\hline (.) & pause $0.2 \mathrm{~s}$. \\
\hline$(0.4)$ & timed pause in seconds \\
\hline$=$ & a turn start immediately after the previous speaker \\
\hline$><$ & fast speech \\
\hline$<>$ & slow speech \\
\hline e::i & lengthening \\
\hline$\circ \circ$ & quiet speech \\
\hline AHA & loud speech \\
\hline.$h h h$ & inhalation \\
\hline hhh. & exhalation \\
\hline .joo & word pronounced during inhalation \\
\hline he he & laughter \\
\hline w(h)ord & plosive (laughter) \\
\hline$£ £$ & smile voice \\
\hline @@ & change in tone \\
\hline$\downarrow$ & low speech \\
\hline (tai) & doubt in transcription \\
\hline$(--)$ & a word unheard \\
\hline$(--)$ & several unhearable words \\
\hline$(())$ & comments by the transcriber \\
\hline\{\} & comments by the transcriber \\
\hline$b$ & fist shaking \\
\hline$\sigma$ & waving a finger \\
\hline$\infty$ & pointing or waving a finger throughout \\
\hline נת בת & singing throughout \\
\hline
\end{tabular}

\section{References}

Adelswärd, Viveka (1989) Laughter and dialogue: The social significance of laughter in institutional discourse. Nordic Journal of Linguistics 12: 107-136.

Álvarez-Cáccamo, Celso (1990) Rethinking conversational code-switching: Codes, speech varieties, and contextualization. In Proceedings of the Sixteenth Annual Meeting of the Berkeley Linguistics Society (February 16-19, 1990). General Session and Parasession on The Legacy of Grice. Berkeley: Berkeley Linguistics Society, pp. 3-16.

Álvarez-Cáccamo, Celso (1996) The power of reflexive language(s): Code displacement in reported speech. Journal of Pragmatics 25.1: 33-59.

Antaki, Charles (1994) Explaining and Arguing: The Social Organization of Accounts. London: Sage. 
Auer, Peter (1995) The pragmatics of code-switching. In L. Milroy, and P. Muysken (eds.), One Speaker, Two Languges: Cross-Disciplinary Perpectives on Code-switching. Cambridge: Cambridge University Press, pp. 115-135.

Auer, Peter (1998) From code-switching via language mixing to fused lects: Toward a dynamic typology of bilingual speech. InList No. 6: 1-27.

Auer, Peter (ed.) (1998) Code-switching in Conversation. London: Routledge.

Bakhtin, Mikhail Mikhailovich (1982 [1934]) Discourse in the novel. In The dialogic imagination: Four essays. Austin: University of Texas Press, pp. 259-422.

Besnier, Niko (1990) Language and affect. Annual Review of Anthropology 19: 419-451.

Blom, Jan-Petter, and John J. Gumperz (1972) Social meaning in linguistic structure: Code-switching in Norway. In J.J. Gumperz, and D.H. Hymes (eds.), Directions in Sociolinguistics. New York: Holt, Rinehart and Winston, pp. 407-434.

Clark, H.H., and R.J. Gerrig (1990) Quotations as demonstrations. Language 66: 764-805.

Couper-Kuhlen, Elizabeth (1999) Coherent voicing: On prosody in conversational reported speech. In W. Bublitz, and U. Lenk (eds.), Coherence in Spoken and Written Discourse: How to create it and how to describe it. Amsterdam: Benjamins Publishing Company, pp. 11-32.

Couper-Kuhlen, Elizabeth (2004) Prosody and sequence organization in English conversation. In E. Couper-Kuhlen, and C.E. Ford (eds.), Sound Patterns in Interaction. Amsterdam: Benjamins Publishing Company, pp. 335-376.

Couper-Kuhlen, Elizabeth (2012) Exploring affiliation in the reception of conversational complaint stories. In A. Peräkylä, and M-L. Sorjonen (eds.), Emotion in interaction. New York: Oxford University Press, pp. 113-146.

Couper-Kuhlen, Elizabeth, and Gabriele Klewitz (1999) Quote - unquote? The role of prosody in the contextualization of reported speech sequences. Pragmatics 9.4: 459-485.

Couper-Kuhlen, Elizabeth, and Sandra A. Thompson (2000) Concessive patterns in conversation. In E. Couper-Kuhlen, and B. Kortmann (eds.), Cause, Condition, Concession, Contrast: Cognitive and Discourse Perspectives. Berlin: Walter de Gruyter, pp. 381-410.

Curl, Traci S., and Paul Drew (2008) Contingency and action: A comparison of two forms of requesting. Research on Language and Social Interaction. 41.2: 129-153.

Drew, Paul (1987) Po-faced receipts of teases. Linguistics 25: 219-253.

Drew, Paul, and Elizabeth Holt (1998) Figures of speech: Figurative expressions and the management of topic transition in conversation. Language in society 27.3: 495-522.

Duranti, Alessandro, and Charles Goodwin (1992) Editors' introduction. In A. Duranti, and C. Goodwin (eds.), Rethinking Context: Language as an interactive phenomenon. Cambridge: Cambridge University Press, p. 229.

Edwards, Derek (2005) Moaning, whinging and laughing: The subjective side of complaints. Discourse Studies 7.1: 5-29.

EKSS = Eesti keele seletav sõnaraamat. Eesti keele instituut. 
http://www.eki.ee/dict/ekss/

Englebretson, Robert (2010) Interactional linguistics. Lecture presented at Langnet course. University of Turku 2.-5.3.2010.

Etelämäki, Marja, and Minna Jaakola (2009) Tota ja puhetilanteen todellisuus. Virittäjä 113: 188-212.

Frick, Maria (2008) Morphological integration of Estonian lexical elements in a Finnish language base. Journal of Linguistic and Intercultural Education 1: 81-95.

Gal, Susan (1979) Language shift: Social determinants of linguistic change in bilingual Austria. Language, thought, and culture: Advances in the study of cognition. New York: Academic Press.

Goffman, Erving (1971) Relations in Public: Microstudies of the Public Order. New York: Harper and Row.

Goffman, Erving (1981) Forms of talk. Oxford: Basil Blackwell.

Goodwin, Marjorie Harness, and Charles Goodwin (2000) Emotion within situated activity. In A. Duranti (ed.), Linguistic Anthropology: A reader. Malden, MA/Oxford: Blackwell, pp. 239-257.

Goyvaerts, Didier, and Tembue Zembele (1992) Codeswitching in Bukavu. Journal of multilingual and multicultural development 13: 71-82.

Grant, Ewan C. (1969) Human Facial Expression. Man, New Series 4: 525-536.

Gumperz, John J (1982) Discourse Strategies. Cambridge: Cambridge University Press,.

Gumperz, John J. (1992) Contextualisation and understanding. In A. Duranti, and C. Goodwin (eds.), Rethinking Context: Language as an interactive phenomenon. Cambridge: Cambridge University Press, p. 230-252.

Günthner, Susanne (1999) Polyphony and the 'layering of voices' in reported dialogues: An analysis of the use of prosodic devices in everyday reported speech. Journal of Pragmatics 31: 685-708.

Haakana, Markku (1995) Vitsi keskustelussa: Kontekstualisointi, tunnistaminen ja sekventiaalisuus. Virittäjä 100: 359-378.

Haakana, Markku (1999) Laughing Matters: A Conversation Analytical Study of Laughter in DoctorPatient Interaction. Helsinki: Department of Finnish Language, University of Helsinki.

Hakulinen, Auli, and Lea Laitinen (2008) Anaforinen nolla: Kielioppia ja affekteja. Virittäjä 112: 162185.

Halmari, Helena (1993) Structural relations and Finnish-English code switching. Linguistics 31: 10431068 .

Heinemann, Trine (2009) Participation and exclusion in third party complaints. Journal of Pragmatics 41: 2435-2451.

ISK = Hakulinen, A., M. Vilkuna, R. Korhonen, V. Koivisto, T.R. Heinonen, and I. Alho (2004) Iso suomen kielioppi. Helsinki: Suomalaisen Kirjallisuuden Seura.

http://scripta.kotus.fi/visk

Jääskeläinen, Anni (2007) Puheen imitatiivikonstruktioita: Proadverbin ja proadjektiivin "sitomat" imitatiivi/ele -konstruktiot puheessa. Presented at Kielitieteen päivät. University of Oulu 24.-25.5.2007. 
Jefferson, G., H. Sacks, and E.A. Schegloff (1987) Notes on laughter in the pursuit of intimacy. In G. Button, and J.R.E. Lee (eds.), Talk and social Organisation. Clevedon: Multilingual Matters, pp. 152205.

Jefferson, Gail (1978) Sequential aspects of storytelling in conversation. In J. Schenkein (ed.), Studies in the organization of conversational interaction. New York: Academic Press, pp. 219-248.

Johanson, Lars (1999) The dynamics of code-copying in language encounters. In B. Brendemoen, E. Lanza, and E. Ryen (eds.), Language encounters across time and space. Oslo: Novus forlag, pp. 37-62.

Kalliokoski, Jyrki (1995) Koodinvaihto ja keskustelun moniäänisyys. Virittäjä 100: 2-24.

Kangasharju, Helena (1998) Alignment in disagreement: Building alliances in multiperson interaction. Manuscript version. Department of Finnish Language. Helsinki: University of Helsinki.

Kangasharju, Helena (2002) Alignment in disagreement: Forming oppositional alliances in committee meetings. Journal of Pragmatics 34: 1447-1471.

Kasterpalu, Riina (2005) Partiklid jah, jaa ning jajaa naaberpaari järelliikmena müügiläbirääkimistes. Keel ja kirjandus 11-12: 873-996.

Keevallik, Leelo (2011) Formats of challenge. International workshop: Social Action Formats: Conversational Patterns in Embodied Interaction 17-19 May 2011. University of Oulu.

Keltner, D., L. Capps, A.M. Kring, R.C. Young, and E.A. Heerey (2001) Just teasing. Psychological Bulletin 127: 229-248.

Koshik, Irene (2003) Wh-questions used as challenges. Discourse Studies 5: 51-77.

Kovács, Magdolna (2001) Code-Switching and Language Shift in Australian Finnish in Comparison with Australian Hungarian. Åbo: Åbo Akademis Förlag.

Laitinen, Lea (1995) Nollapersoona. Virittäjä 99: 337-358.

Lappalainen, Hanna (2004) Variaatio ja sen funktiot. Erään sosiaalisen verkoston jäsenten kielellisen variaation ja vuorovaikutuksen tarkastelua. Helsinki: Suomalaisen kirjallisuuden seura.

Laury, Ritva (1997) Demonstratives in interaction: The emergence of a definite article in Finnish. Studies in discourse and grammar. Volume 7. Amsterdam: John Benjamins Publishing Company.

Laury, Ritva, and Marja Etelämäki (p.c.) Personal communication 02.05.2011.

Lehtimaja, Inkeri (2006) Oppilaiden välinen kiusoittelu luokkahuonekeskustelussa. In S. Kurhila, and A. Mäntynen (eds.), Tunnetta mukana. Kirjoituksia Jyrki Kalliokosken 50-vuotispäivän kunniaksi. Kieli 17. Helsinki: Helsingin yliopisto, suomen kielen ja kotimaisen kirjallisuuden laitos, pp. 55-73.

Leisiö, Larisa (1998) Code-Switching in Reported Speech. In J. Verschueren (ed.), Pragmatics in 1998: Selected papers from the $6^{\text {th }}$ International Pragmatics Conference, Vol. 2. Antwerp: International Pragmatics Association, pp. 349-362.

Li Wei (2002) What do you want me to say? On the Conversation Analysis approach to bilingual interaction. Language in Society 31: 159-180. 
Lo, Adrienne (1999) Codeswitching, speech community membership, and the construction of ethnic identity. Journal of Sociolinguistics 3.4: 461-479.

Mägiste, Julius (1949) Eesti abielu ja soome avio. In Apophoreta Tartuensia. Stockholm: Eesti Teaduslik Selts.

McClure, Erika (1977) Aspects of code-switching in the discourse of bilingual Mexican-American children. Technical report No. 44. Illinois Univ., Urbana. Center for the Study of Reading. Cambridge: Bolt, Beranek and Newman, Inc., http://eric.ed.gov/PDFS/ED142975.pdf retrieved 02.06.2011

McNeill, David (1992) Hand and mind: What gestures reveal about thought. Chicago: The University of Chicago Press.

Muysken, Pieter (2000) Bilingual speech: A typology of code-mixing. Cambridge: Cambridge University Press.

Myers-Scotton, Carol (1992) Comparing codeswitching and borrowing. In C.M. Eastman (ed.), Codeswitching. Multilingual matters 89. Clevedon: Multilingual Matters Ltd, pp. 19-39.

Niemelä, Maarit (2010) The reporting space in conversational storytelling: Orchestrating all semiotic channels for taking a stance. Journal of Pragmatics 42: 3258-3270.

Norrick, Neil R., and Alice Spitz (2008) Humor as a resource for mitigating conflict in interaction. Journal of Pragmatics 40: 1661-1686.

Ochs, Elinor, and Bambi Schieffelin (1989) Language has a heart. Text 9: 7-25.

Poplack, Shana (2000 [1980]) Sometimes I'll start a sentence in Spanish y termino en espanol: Toward a typology of code-switching. In Li Wei (ed.), The Bilingualism Reader. London: Routledge, pp. 213-243.

Raevaara, Liisa (2009) Nyt täytyy ostaa kun tuli vähä rahaa tosta monivedosta. Asiakkaan ja myyjän kootut selitykset. In H. Lappalainen, and L. Raevaara (eds.), Kieli kioskilla. Tutkimuksia kioskiasioinnin rutiineista. Tietolipas 219. Helsinki, Suomalaisen kirjallisuuden seura, pp. 231-262.

Rampton, Ben (2006) Language in late modernity: Interaction in an urban school. Studies in Interactional Sociolinguistic 22. Cambridge: Cambridge University Press.

Saari, Mirja (2009) Kielten kohtaaminen autonomian ajan Suomessa. In J. Kalliokoski, L. Kotilainen, and P. Pahta (eds.), Kielet Kohtaavat. Tietolipas 227. Helsinki: Suomalaisen Kirjallisuuden Seura, pp. 212230.

Sacks, Harvey (1995) Lectures on Conversation. Volumes I and II. Gail Jefferson (ed.), Oxford: Blackwell.

Schegloff, Emanuel A. (2001) Getting serious: Joke $\rightarrow$ serious 'no'. Journal of Pragmatics 33: 19471955.

Schegloff, Emanuel A. (2005) Whistling in the dark: Notes from the other side of liminality'. Texas Linguistic Forum 48: 17-30.

Schegloff, Emanuel A. (2007) Sequence Organization in Interaction: A Primer in Conversation Analysis, Vol. 1. Cambridge: Cambridge University Press.

Schegloff, Emanuel, and Harvey Sacks (1973) Opening up closings. Semiotica 7: 289-327.

Scott, Marvin B., and Stanford M. Lyman (1968) Accounts. American Sociological Review 33: 46-62. 
Selting, Margret (1994) Emphatic speech style: With special focus on the prosodic signalling of heightened emotive involvement in conversation. Journal of pragmatics 22: 375-408.

Selting, Margret (2010) Affectivity in conversational storytelling. An analysis of displays of anger or indignation in complaint stories. Pragmatics 20: 229-277.

Sorjonen, Marja-Leena (2001) Responding in conversation: A study of response particles in Finnish. Pragmatics \& Beyond, New Series. 70. Amsterdam: John Benjamins Publishing Company.

Stivers, Tanya (2008) Stance, alignment, and affiliation during storytelling: When nodding is a token of affiliation. Research on Language and Social Interaction 41.1: 31-57.

Tainio, Liisa (2001) Ikääntyneiden pariskuntien identiteetit. In Puhuvan naisen paikka. Sukupuoli kulttuurisena kategoriana kielenkäytössä. Helsinki: Suomalaisen kirjallisuuden seura, pp. 233-244.

Volosinov (1973) Marxism and the philosophy of language. Studies in Language. New York: Seminar Press.

Vuchinich, Samuel (1990) The sequential organization of closing in verbal family conflict. In A. Grimshaw (ed.), Conflict Talk: Sociolinguistic investigations of arguments in conversations. Cambridge: Cambridge University Press, pp. 118-138.

Yli-Vakkuri, Valma (1986) Suomen kieliopillisten muotojen toissijainen käyttö. Turku: Turun yliopisto.

Zabrodskaja, Anastassia (2005) Vene-eesti koodivahetus Kohtla-Jarve vene emakeelega algkoolilastel. Tallinna Ulikooli eesti filololoogia osakonna toimetised 6. Tallinn: Tallinna Ulikooli Kirjastus.

Zentella, A.C. (1997) Growing up bilingual: Puerto Rican children in New York. Oxford: Blackwell.

MARIA FRICK is completing a Ph.D. at the University of Helsinki, Department of Finnish, Finno-Ugrian and Scandinavian Studies, where she works in the FiDiPro project "Grammar and interaction: The linking of actions in speech and writing".

Address: Department of Finnish, Finno-Ugrian and Scandinavian Studies, PL 3 / Fabianinkatu 33, FIN00014 Helsingin yliopisto, Finland. E-mail: maria.frick@helsinki.fi 